\title{
Figuring Figures: Exploring Europeans' Knowledge of Official Economic Statistics
}

\author{
Maria R. Vicente ${ }^{1}$ and Ana J. López ${ }^{1}$
}

\begin{abstract}
Economic issues have been a major concern for Europeans in the last few years. In this context, it is reasonable to suppose that people are aware of the main economic figures regarding Europe. But are they really familiar with them? Do they know what the rates of growth, unemployment and inflation are?

The aim of this article is to explore the level of knowledge of these three economic indicators among Europeans. Several regression models are specified and estimated in order to identify the relationship between an individual's knowledge and their socioeconomic profile, use of the Internet, perceived importance of economic issues and official statistics and trust in them. Cross-country differences are also assessed.
\end{abstract}

Key words: Economic indicators; European Union; literacy; misperception.

\section{Introduction}

In June 2010, the United Nations General Assembly adopted 20 October 2010 as the first World Statistics Day (United Nations General Assembly 2010). Such a declaration aimed to acknowledge the importance of official statistics as an indispensable element for both individual and collective informed decision-making (OECD 2005; United Nations General Assembly 2010). Reliable and objective statistics are the basis for democratic societies to function properly: not only are statistics a key input for policy-makers at all levels (European, national, local) but they also serve the public by providing an accurate picture of the current economy and society (Rose 1991; Gal 2002; Ottaviani 2002; Wild 2005; Holt 2008; Eurostat 2016a). Despite their fundamental importance, there is a major concern about the level of public knowledge of official statistics. Research in the United States (US) has shown that the level of knowledge is not high (Blendon et al. 1997; Blinder and Krueger 2004; Curtin 2008, 2009): even though 58\% of US adults report knowing the latest rate of unemployment, less than one quarter (25\%) indicate that they are familiar with the latest figures of Gross Domestic Product (GDP) growth or inflation (Curtin 2009). In Europe, the empirical evidence is limited (Papacostas 2008; Giovannini et al. 2015 for Italy) and many times the term 'knowledge' refers to being aware of the national statistical

${ }^{1}$ University of Oviedo - Applied Economics, Campus del Cristo s/n, Oviedo 33006, Spain. Emails: mrosalia@uniovi.es and anaj@uniovi.es

Acknowledgments: The authors would like to thank the editor and referees for their comments on previous versions of the manuscript. We also thank for the comments made by participants at the session on Statistical Literacy at the European Conference on Quality in Official Statistics, held in Madrid in June 2016. 
offices rather than actual knowledge of official figures (Natcen 2015; Northern Ireland Statistics and Research Agency 2015).

In this context, this article tries to contribute to bridging this gap in research by providing some evidence of Europeans' knowledge of official economic statistics. Results can provide useful insights to identifying those groups which know little about economic statistics, and thus to design appropriate measures to improve general knowledge in society. In particular, attention is paid to the figures of GDP, unemployment and inflation.

\section{Background}

The role of information in markets and agents' decisions has been a major issue in the economic literature. Neoclassical economists consider that individuals are not only rational but they also have perfect information about the relevant conditions of the economy.

Later theories and models have criticized severely these assumptions and led to the introduction of incomplete and asymmetrical information into economic models. It is then argued that in market transactions, agents have limited information (Lucas 1972; Townsend 1983); additionally, one of the parties might know more than the other (Akerlof 1970).

In this context, rational inattention and sticky information models state that information acquisition involves some costs (Sims 2003), including the time and money of obtaining, processing, and analyzing information and deciding how to use it (Reis 2006). Moreover, costs might vary among individuals, being substantial for those who either do not know how and where to obtain information or do not have the skills to process and understand it (Sims 2003; Blinder and Krueger 2004). Therefore, it is postulated that, for some individuals, the costs might exceed the perceived benefits derived from information; consequently, they would rationally choose not to update (Mankiw and Reis 2002; Sims 2003; Bacchetta and van Wincoop 2005; Reis 2006). Additionally, some authors have hypothesized that individuals' demand for information might differ depending on the sources checked, the volume of news and their type (Akerlof et al. 2000; Souleles 2001; Carroll 2003; Blinder and Krueger 2004; Curtin 2009). In this sense, Kahneman and Tversky (1979) suggest that agents are more receptive towards bad news than good news.

Modern theories have also introduced information heterogeneity into economic models. Thus, individuals might base their decisions on different sets of information. In particular, it is considered that the relevant information for individuals' decisions varies both across people and time depending on their personal circumstances and interests (Blendon et al. 1997; Bryan and Venkatu 2001; Souleles 2001; Blinder and Krueger 2004; Curtin 2008, 2009). An individual might find unemployment figures in his region and sector of activity more meaningful than the national unemployment rate (Curtin 2008; Cardoso et al. 2016).

In this context, empirical evidence has shown that much of the population appears to be rather inattentive to the information stemming from official statistics. Moreover, there are significant gaps of knowledge across socioeconomic groups (Blendon et al. 1997; Walstad 1997; Walstad and Rebeck 2002; Blinder and Krueger 2004; Curtin 2008, 2009; Papacostas 2008; Giovannini et al. 2015). 


\section{Data Description}

The data used in this article come from the Eurobarometer 83.3 carried out on behalf of the European Commission (2015a) in May 2015, and cover the population of individuals aged 15 years and older living in one of the 28 Member States of the European Union. A multistage, stratified random sample design was applied in each country in order to guarantee that the sample drawn was representative of the population. Fieldwork ran from May 16 to May 27, 2015. A total 27,758 interviews were successfully made. Among these, 27,745 individuals provided information on their knowledge of official statistics, specifically, of the rates of GDP growth, inflation and unemployment. Eurostat (2016b) defines Gross Domestic Product as a measure of the economic activity that takes into account the value of all goods and services produced, minus the value of the goods or services used in their production. The inflation rate is defined as the percentage change in the price level in a certain period (Eurostat 2016c). The unemployment rate refers to the proportion of unemployed people as part of the total labor force; an unemployed person is defined as a person aged 15-74 years old who does not have a job during the reference week, is actively seeking work, and is available to start working within the next two weeks (Eurostat 2016d).

Sampled individuals were asked about such indicators in the following terms:

"What was the official growth rate of the economy (measured in terms of Gross Domestic Product) in your country in 2014? I can tell you that this figure is between $-5 \%$ and $15 \%$.

What was the official inflation rate, the rate at which consumer prices increased or decreased, in your country in 2014? I can tell you that the exact figure is between $-5 \%$ and $20 \%$.

Do you think that, in your country, the inflation rate in 2014 was higher, lower or equal to the rate in 2013 ?

What was the official unemployment rate, the percentage of active people who do not have a job, in your country in 2014 ? I can tell you that the exact figure is between $0 \%$ and 30\%" (European Commission 2015a, 35-36).

Answering these questions might place different cognitive burdens on respondents. As previous research notes (Curtin 2008, 2009), the unemployment rate is the most popular and the easiest indicator to remember, since it is a simple proportion. In contrast, the inflation rate is quite a complex figure to remember: while the rise (decrease) of prices has a direct impact on people's life, recalling its rate of change is difficult since several figures are usually reported at the same time (monthly and annual rates, general and core inflation). In the same sense, the growth rate is a difficult figure to remember: on the one hand, the public is less familiar with the measure of GDP; on the other hand, it is reported quarterly and annually, in nominal and real terms, and its figures are usually revised.

Moreover, it is important to note that the questions provide some guidelines for the answers. In particular, the questionnaire indicates that the rates go from $-5 \%$ to $+15 \%$ for growth, from $-5 \%$ to $+20 \%$ for inflation and from $0 \%$ to $+30 \%$ for unemployment. The provision of this kind of guidelines typically has some effect on responses. On the one hand, it might prevent people from reporting numbers that make little sense. This would contribute, at least to some extent, to the accuracy of responses. In the particular case of growth and inflation, these guidelines might help respondents to be aware of potential 
negative rates that are less intuitive than positive figures. On the other hand, these guidelines could alter people's responses, diverting them from the actual figures they recall. Whether the provision of these guidelines has a net positive or negative effect on accuracy is difficult to assess: they might help some respondents to provide more accurate figures, while for others it could have the opposite effect. Unfortunately, the survey does not have enough information to be able to disentangle such effects. Additionally, we should consider that the provided guidelines are the same for all member countries. Since there is substantial variation in economic figures across nations, some evidence of these cross-country differences may be found in the country constants when running regressions.

Table 1 shows the percentages of 'don't know' answers for the questions on the economic indicators. As just indicated, growth and inflation rates seem to be the most difficult figures to remember: $31 \%$ of Europeans indicate that they cannot recall them.

Table 1. Europeans' 'don't know' rates when asked about the official figures of growth, inflation and unemployment (in percent).

\begin{tabular}{|c|c|c|c|}
\hline & Growth rate & Inflation rate & Unemployment rate \\
\hline & \multicolumn{3}{|c|}{$\%$ of 'don't know' answers } \\
\hline European Union & 31 & 31 & 20 \\
\hline Austria & 12 & 9 & 6 \\
\hline Belgium & 46 & 44 & 29 \\
\hline Bulgaria & 55 & 52 & 41 \\
\hline Croatia & 29 & 30 & 23 \\
\hline Cyprus & 50 & 52 & 25 \\
\hline Czech Republic & 24 & 22 & 11 \\
\hline Denmark & 27 & 24 & 13 \\
\hline Estonia & 15 & 19 & 14 \\
\hline Finland & 24 & 24 & 12 \\
\hline France & 37 & 37 & 20 \\
\hline Germany & 30 & 27 & 18 \\
\hline Greece & 37 & 39 & 11 \\
\hline Hungary & 28 & 22 & 15 \\
\hline Ireland & 23 & 23 & 18 \\
\hline Italy & 30 & 30 & 20 \\
\hline Latvia & 52 & 48 & 36 \\
\hline Lithuania & 40 & 43 & 27 \\
\hline Luxembourg & 42 & 41 & 21 \\
\hline Malta & 37 & 39 & 35 \\
\hline Netherlands & 10 & 13 & 9 \\
\hline Poland & 13 & 11 & 8 \\
\hline Portugal & 56 & 56 & 37 \\
\hline Romania & 67 & 67 & 58 \\
\hline Slovakia & 44 & 40 & 18 \\
\hline Slovenia & 32 & 35 & 22 \\
\hline Spain & 40 & 42 & 24 \\
\hline Sweden & 12 & 12 & 3 \\
\hline United Kingdom & 24 & 23 & 23 \\
\hline
\end{tabular}

Source: Own elaboration using data from the European Commission (2015a). 


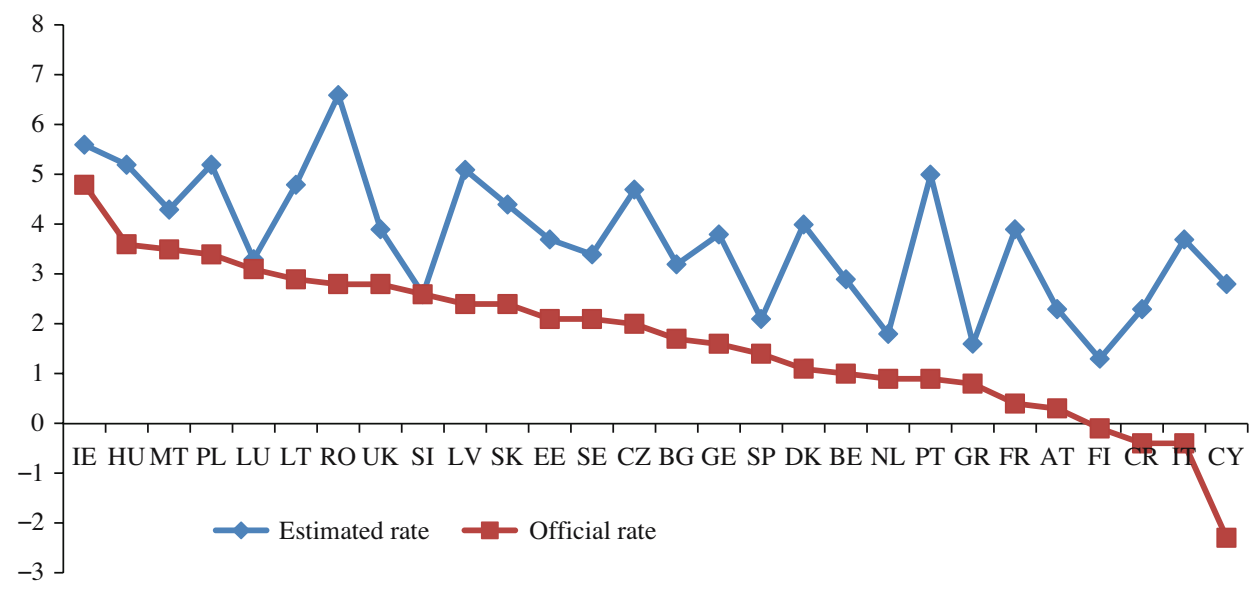

Fig. 1. Estimated and official annual growth rates in the Member States of the European Union in 2014 (in percent). Source: Own elaboration using data from the European Commission (2015a,c). Notes: Countries have been sorted in descending order of the official figure. Countries' acronyms are the following: AT-Austria, BEBelgium, BG-Bulgaria, CR-Croatia, CY-Cyprus, CZ-Czech Republic, DK-Denmark, EE-Estonia, FI-Finland, FR-France, GE-Germany, GR-Greece, HU-Hungary, IE-Ireland, IT-Italy, LT-Lithuania, LV-Latvia, LULuxembourg, MT-Malta, NL-Netherlands, PL-Poland, PT-Portugal, RO-Romania, SE-Sweden, SI-Slovenia, SK-Slovakia, SP-Spain and UK-United Kingdom.

In the case of unemployment, the percentage of 'don't know' answers is $20 \%$. Nonetheless, there is great variation across countries.

Figures 1-3 show the average estimated rates from respondents' answers together with the official rates as reported by the European Commission in its Spring Economic Forecast $(2015 b, c)$. These Commission forecasts were released on May 5, 2015. We can see that official numbers are being overestimated practically everywhere.

Concerning growth, figures are overrated in all the countries except for Slovenia and Luxembourg, where respondents provide figures that are very close to the official rates.

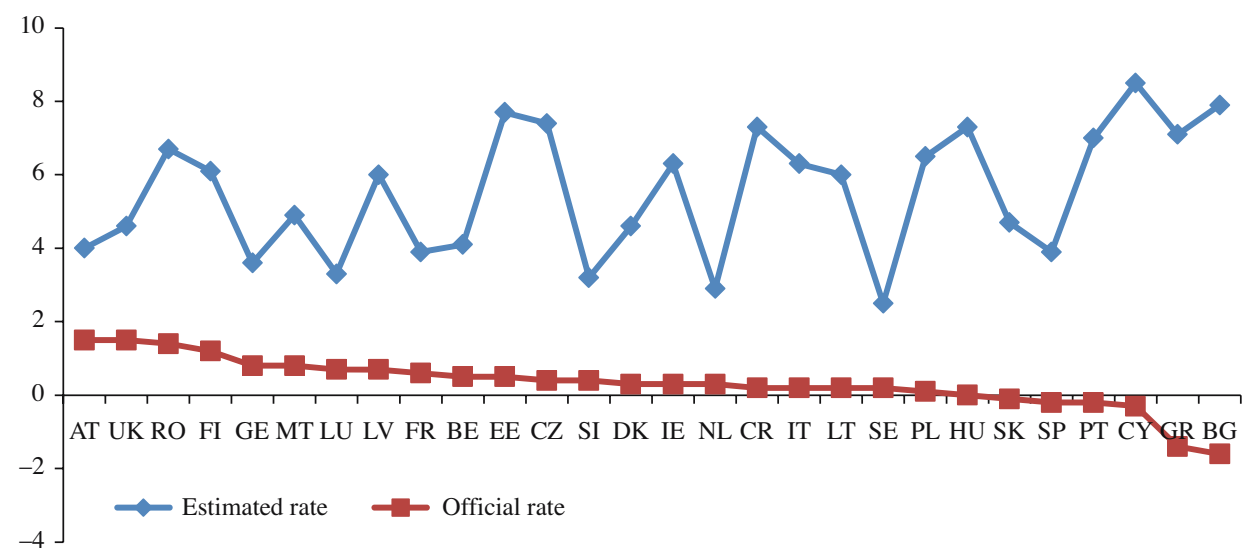

Fig. 2. Estimated and official annual inflation rates in the Member States of the European Union in 2014 (in percent). Source: Own elaboration using data from the European Commission (2015a,c). Notes: See notes under Figure 1. 


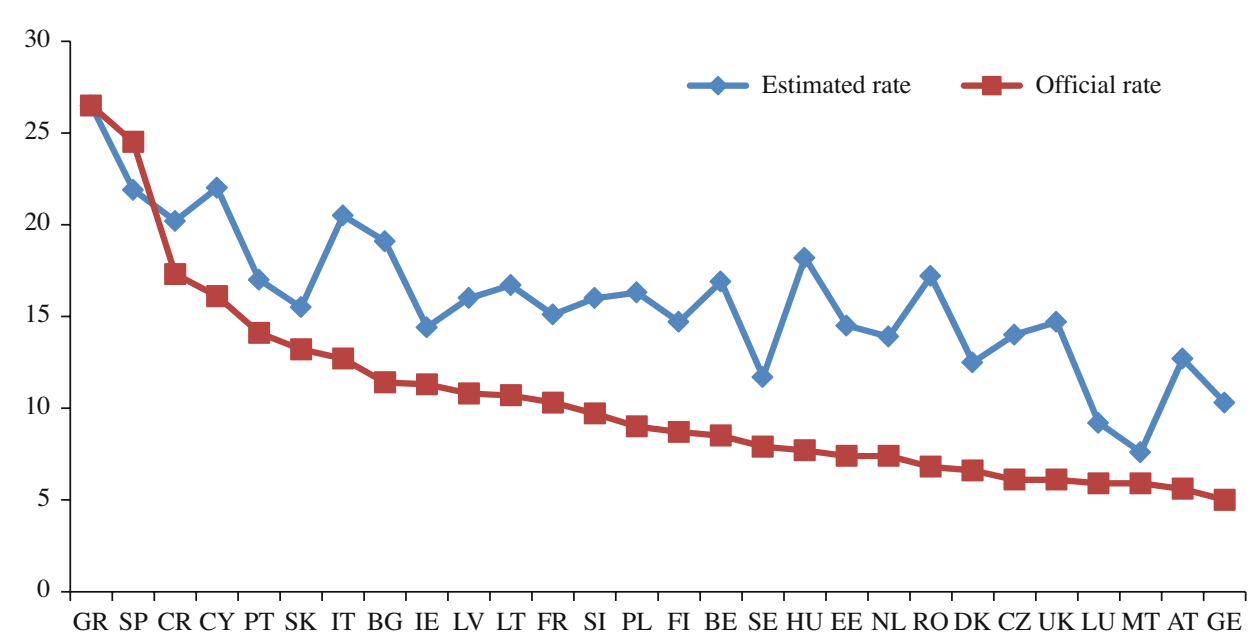

Fig. 3. Estimated and official unemployment rates in the Member States of the European Union in 2014 (in percent). Source: Own elaboration using data from the European Commission (2015a,c). Notes: See notes under Figure 1.

The biggest differences are found in Romania, Portugal, Italy, and Cyprus. In fact, Italy and Cyprus both have negative rates of growth $(-0.4 \%$ and $-2.3 \%$, respectively), whereas the average estimated rates of respondents' answers are positive $(3.7 \%$ and $2.8 \%$, respectively).

Inflation rates are also overestimated across the Union: while the official rates vary between $-1.6 \%$ and $1.5 \%$, the estimated rates are between $2.3 \%$ and $8.5 \%$. The largest differences are generally observed in countries with negative rates of inflation: in Bulgaria, the average of people's answers is 9.5 points higher than the official rate $(7.9 \%$ versus $-1.6 \%)$; in Cyprus the gap is 8.8 points $(8.5 \%$ versus $-0.3 \%)$.

Likewise, unemployment figures suffer from overestimation. The only exceptions are Greece and Spain, the countries with the largest figures on unemployment (over 20\%): Greek respondents provide a fairly accurate estimate of the official figure; while the Spanish underestimate the rate by 2.6 points.

It is worth noticing that some of the observed overestimation could be due to the guideline values included in the questionnaire. As previously explained, the survey does not contain the appropriate information to check this. Nonetheless, previous research has also found that people tend to overestimate the rates of growth, inflation and unemployment (Papacostas 2008) even when respondents are not provided with any guidelines for answers (Blendon et al. 1997; Curtin 2008, 2009; Malgarini 2009; Giovannini et al. 2015).

Some authors have attempted to provide some explanations for the overestimation of economic figures (European Commission 2007; Curtin 2008; Malgarini 2009). According to Curtin (2008), the overestimation of inflation and unemployment rates is related to a psychological process by which people hold pessimistic views to protect themselves from unexpected events. The European Commission (2007) considers that the overestimation of unemployment figures may well be an indication of the importance that citizens place on this issue. For the particular case of inflation, Malgarini (2009) explains that people might not know the exact meaning of this economic concept as measured by statistical offices. 
Table 2. Estimated rates of growth, inflation and unemployment according to respondents' views on the economic situation. European estimated average rates and number of respondents.

\begin{tabular}{lccc}
\hline $\begin{array}{l}\text { Perception of the } \\
\text { economic situation }\end{array}$ & Growth rate & Inflation rate & Unemployment rate \\
\hline Very good & 3.8 & 3.5 & 10.0 \\
Rather good & $(749)$ & $(775)$ & $(828)$ \\
& 4.0 & 4.3 & 12.9 \\
Rather bad & $(7,000)$ & $(7,032)$ & $(7,746)$ \\
& 3.7 & 5.1 & 17.1 \\
Very bad & $(7,153)$ & $(7,237)$ & $(8,596)$ \\
& 3.2 & 6.2 & 20.7 \\
Don't know & $(3,319)$ & $(3,329)$ & $(4,254)$ \\
& 4.7 & 5.6 & 15.6 \\
Total & $(352)$ & $(356)$ & $(413)$ \\
& 3.7 & 4.9 & 15.9 \\
\hline
\end{tabular}

Source: Own elaboration using data from the European Commission (2015a).

Note: The number of respondents is shown in brackets.

Hence, when they are asked to report a figure, the number they recall is based on their personal experiences. Moreover, people's perceptions are related to their socioeconomic background (i.e., the same increase in prices is felt differently by low-income and highincome households). Additionally, responses might be influenced by people's perceptions on the general economic situation. Since our data have some information on people's opinions about the situation of the national economy, we have tried to analyze whether the overestimation of economic figures can be related to these views. Table 2 reports the European averages estimated from respondents' answers disaggregated according to their views on the economic situation. Results show that most respondents have negative opinions on the situation of the economy. Moreover, we can see that the less favorable opinions on the economy, the higher the reported inflation and unemployment and the lower the growth. Hence, it seems that the overestimation of rates might be related, at least to some extent, to the prevalence of negative views on the economic situation.

Table 3 shows respondents' answers when asked about the evolution of inflation between 2013 and 2014. The percentage of 'don't know' answers is much lower in this case than when people were requested to provide a figure (18\% vs. $31 \%$ ), since it is easier to remember the general evolution of a magnitude than its exact figure. In half of the countries, the most popular answer was that the inflation rate was higher; however, the inflation rate was lower in 2014 than in 2013 in all European Union's countries, except for Latvia.

\section{Empirical Approach and Variables}

\subsection{Empirical Approach}

In order to analyze Europeans' knowledge of official economic statistics, we have identified the case in which respondents were asked to provide a figure from the case in which they reported the evolution of the inflation rate. 
Table 3. Estimated evolution of the inflation rate between 2013 and 2014 (in percent).

\begin{tabular}{lccccc}
\hline & Higher & Lower & Equal & Don't know & Total \\
\hline European Union & 29 & $\mathbf{3 0}$ & 23 & 18 & 100 \\
Austria & 50 & $\mathbf{2 5}$ & 19 & 6 & 100 \\
Belgium & 32 & $\mathbf{3 2}$ & 18 & 18 & 100 \\
Bulgaria & 34 & $\mathbf{1 4}$ & 21 & 31 & 100 \\
Croatia & 40 & $\mathbf{1 9}$ & 30 & 11 & 100 \\
Cyprus & 40 & $\mathbf{1 5}$ & 21 & 24 & 100 \\
Czech Republic & 27 & $\mathbf{3 2}$ & 31 & 10 & 100 \\
Denmark & 36 & $\mathbf{2 7}$ & 28 & 9 & 100 \\
Estonia & 36 & $\mathbf{2 6}$ & 19 & 19 & 100 \\
Finland & 27 & $\mathbf{2 8}$ & 29 & 16 & 100 \\
France & 34 & $\mathbf{2 4}$ & 18 & 24 & 100 \\
Germany & 24 & $\mathbf{3 6}$ & 23 & 17 & 100 \\
Greece & 40 & $\mathbf{1 9}$ & 24 & 17 & 100 \\
Hungary & 27 & $\mathbf{4 5}$ & 22 & 6 & 100 \\
Ireland & 41 & $\mathbf{2 2}$ & 24 & 13 & 100 \\
Italy & 26 & $\mathbf{2 7}$ & 31 & 16 & 100 \\
Latvia & $\mathbf{3 3}$ & 28 & 23 & 16 & 100 \\
Lithuania & 34 & $\mathbf{3 3}$ & 17 & 16 & 100 \\
Luxembourg & 30 & $\mathbf{3 1}$ & 20 & 19 & 100 \\
Malta & 28 & $\mathbf{2 9}$ & 19 & 24 & 100 \\
Netherlands & 36 & $\mathbf{4 0}$ & 19 & 5 & 100 \\
Poland & 22 & $\mathbf{2 8}$ & 30 & 20 & 100 \\
Portugal & 34 & $\mathbf{1 9}$ & 23 & 24 & 100 \\
Romania & 29 & $\mathbf{3 3}$ & 18 & 20 & 100 \\
Slovakia & 20 & $\mathbf{3 0}$ & 35 & 15 & 100 \\
Slovenia & 22 & $\mathbf{3 5}$ & 27 & 16 & 100 \\
Spain & 29 & $\mathbf{2 5}$ & 19 & 27 & 3 \\
Sweden & 27 & $\mathbf{4 7}$ & 23 & 16 & \\
United Kingdom & 31 & $\mathbf{3 7}$ & 16 & & 100 \\
\hline Sor & & & & & \\
\hline
\end{tabular}

Source: Own elaboration using data from the European Commission (2015a,b).

Note: Bold numbers indicate the actual evolution of the inflation rate.

In the first case, a two-stage decision process was considered: first, an individual decides whether or not to answer the questions about economic statistics; then, if he decides to answer, he provides a figure.

The most appropriate framework for analyzing an individual's first decision is discrete choice modelling. Since there might be some relationship between those who decide to answer the three questions, a trivariate probit model was considered rather than estimating three separate equations. The model can be defined as a latent variable model as follows (Cappellari and Jenkins 2003):

$$
y_{m}^{*}=\boldsymbol{\beta}_{\mathbf{m}}^{\prime} \mathbf{X}+e_{m} \quad y_{m}=1\left[y_{m}^{*}>0\right] \quad m=1,2,3
$$

where $y_{m}^{*}$ is a latent variable and only $y_{m}$ is observed, being a binary variable that takes value 1 if the individual decides to answer question $\mathrm{m}$ ( 0 otherwise); $\mathbf{X}$ is the vector of explanatory variables, and $e_{m}$ is the error terms that are distributed as multivariate normal 
with zero-mean and a variance-covariance matrix with ones in the leading diagonal and correlations $\rho_{\mathrm{jk}}=\rho_{\mathrm{kj}}$ as off-diagonal elements. The trivariate probit model allows the specification of different sets of regressors for each Equation $\left(\mathbf{X}_{\mathbf{m}}\right)$. However, in our specification we are interested in checking the influence of the same set of explanatory variables.

In the second stage, for those individuals who decide to answer and provide an estimate, the errors are evaluated. Given that the sample is restricted to those individuals who actually provided a figure, there could be some sample selection bias. The estimation of Heckman selection models indicates that sample selection bias is not an issue here. Hence, we calculate how much their estimates differ (in absolute value) from the corresponding official figure. Following the approach of the first stage, three linear regressions are estimated jointly. The trivariate regression model is specified as follows:

$$
z_{m}=\boldsymbol{\gamma}_{\mathbf{m}}^{\prime} \mathbf{X}+u_{m} \quad m=1,2,3
$$

where $z_{m}$ refers to the magnitude of the errors (in absolute value) made when reporting the figures of GDP, inflation and unemployment, respectively; $\mathbf{X}$ is the vector of explanatory variables, and $u_{m}$ the error terms that can be correlated between equations. Multivariate regression requires the set of explanatory variables to be the same across all the equations. Moreover, it will produce the same coefficients and standard errors as the ones obtained if the equations are estimated independently. The difference is that the former model allows for obtaining the between-equation covariances.

Since GDP, unemployment, and inflation are measured on different scales, it could be appropriate to consider standardized measures of the absolute errors as dependent variables. Results are shown in the Appendix.

Regarding the evolution of the inflation rate, a multinomial probit model has been specified in order to consider whether respondents gave a right answer, a wrong one or did not know what happened with inflation between 2013 and 2014. The multinomial probit model can be written as:

$$
w_{j}^{*}=\boldsymbol{\varphi}_{\mathbf{j}}^{\prime} \mathbf{X}+v_{j} \quad j=1,2,3
$$

where $w_{j}^{*}$ is the latent variable associated with choice $\mathrm{j}$ and the observable dependent variable $w$ equals $\mathrm{j}$ only if $w_{j}^{*}>w_{m}^{*}$ for all $j \neq m ; \mathbf{X}$ is the vector of explanatory variables, and $v_{j}$ is the error terms which follow independently and identically standard normal distribution. The multinomial probit model has been preferred over multinomial logit model, since it relaxes the independence from irrelevant alternatives (IIA) assumed by the logit (Greene 2011).

\subsection{Variables}

Europeans' knowledge of economic statistics is measured by a series of variables derived from respondents' answers to the questions included in the survey (Section 3). In the first instance, three dummy variables are considered to take into account whether a respondent agreed to answer the questions on the economic figures. Then, for those who decide to answer, the difference between their estimates and the corresponding official rate is 
measured in absolute value. Finally, a categorical variable measures individuals' knowledge of the evolution of inflation. In particular, it is considered whether an individual gave a correct answer, was wrong or did not know.

Explanatory variables have been chosen according to the literature review in Section 2. In particular, Blinder and Krueger (2004) specify that knowledge is a function of an individual's self-interest in the issue, the sources he has checked and his personal characteristics. We complement this approach by taking into account the importance the individual places on official statistics and the individual's trust in them.

Table 4 shows the description of the variables. In the first instance, a measure of an individual's self-interest in economic issues has been defined. This factor is proxied by a dummy variable that indicates whether an individual considers his country's economic situation to be an important issue. In the second instance, daily use of the Internet is included as a proxy for information sources. The Internet has substantially facilitated access to economic information by decreasing associated costs. While television and newspapers seem to be the most common sources of information about the economy (Curtin 2008, 2009; Giovannini et al. 2015), more and more individuals use the Internet to read and watch news. Eurostat (2016e) reports that $45 \%$ of the European population read news online in 2012; this figure exceeds $70 \%$ in Estonia and Denmark, and exceeds $80 \%$ in Finland and Sweden. Moreover, the Internet ranks second (television is ranked first) as the main source of information on national political matters (European Commission 2015d). In this sense, Giovannini et al. (2015) find that together with opinion and political leaders, the Internet is the most significant source of economic information among Italian consumers. Likewise, Curtin (2008) finds evidence of positive correlation between Internet use and knowledge of economic indicators. Nonetheless, Internet use might be linked to some costs for individuals who do not have the ability to find, process and understand information. We control for this fact by including educational attainment. Other socioeconomic features are also considered: gender, age, employment status, social class, and town size. In particular, age, education and income are expected to be positively related to economic knowledge. Compared to younger people, older individuals will a priori have better knowledge because they have had more time to gain an understanding of how the economy works and, consequently, the importance of economic figures (Walstad 1997). Nonetheless, the relationship between age and knowledge might be nonlinear. People with higher education will also have better knowledge because they are more literate and hence, they can better appreciate and understand the importance and meaning of economic figures. Likewise, people with high income are more likely to be interested and know about economic issues than individuals with low income (Walstad 1997). In addition, we consider two dummy variables that take into account whether an individual trusts official statistics, and whether he considers that political decisions are based on them. Finally, country dummies will be included in the estimations in order to control for cross-country differences.

\section{Results}

Tables 5, 6, and 8 show the results of the estimations. Table 5 presents the estimates of the trivariate probit regression, which refers to an individual's decision to answer the 


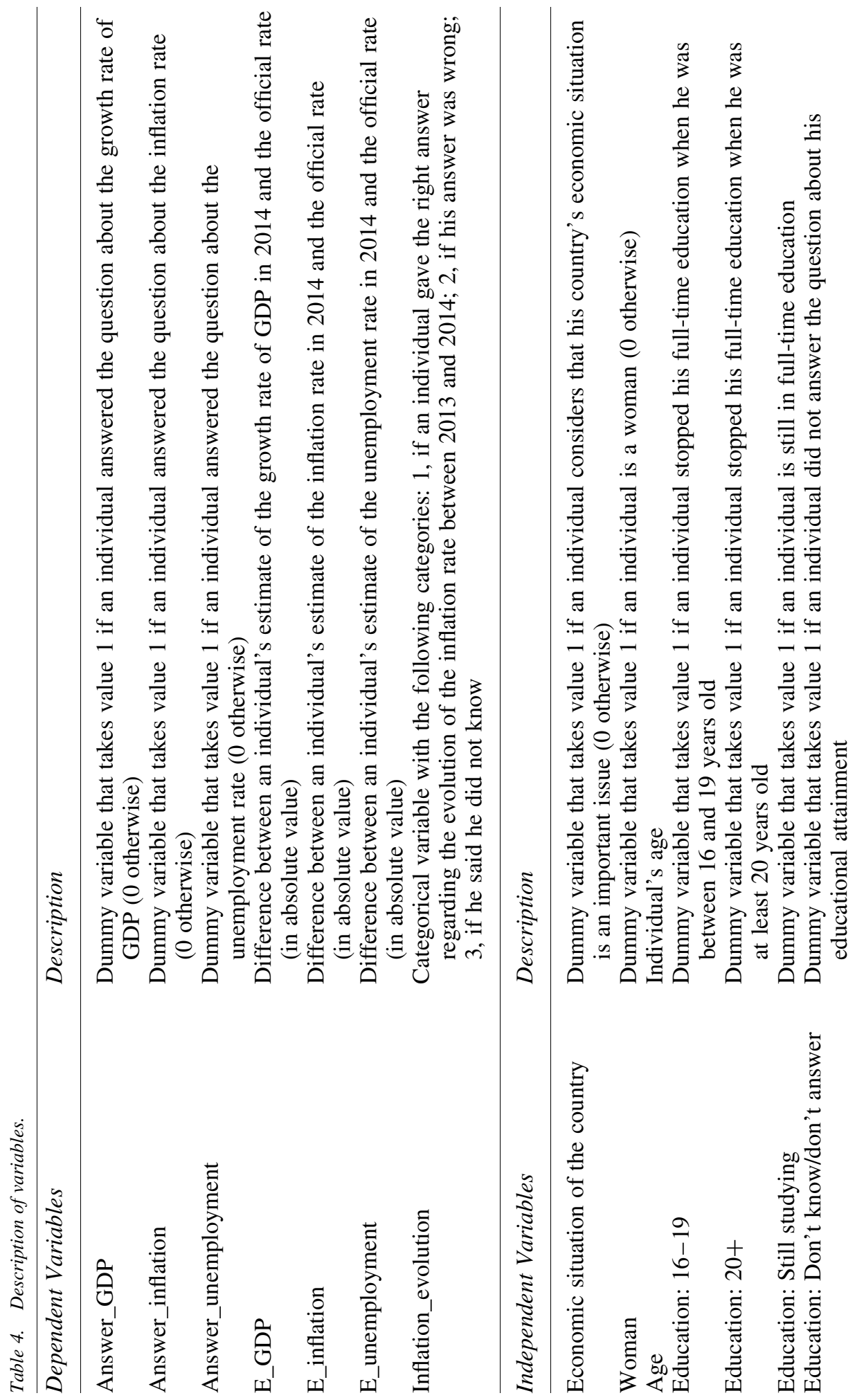




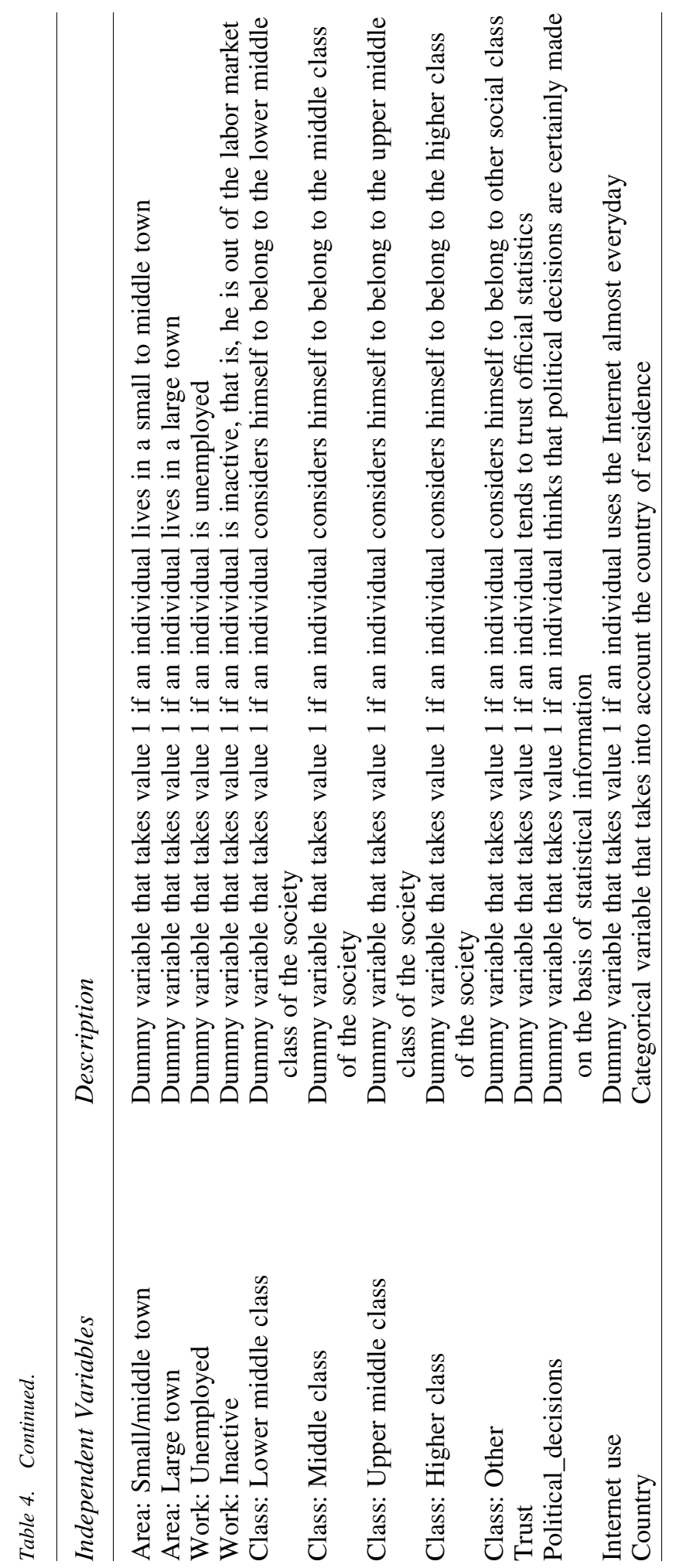




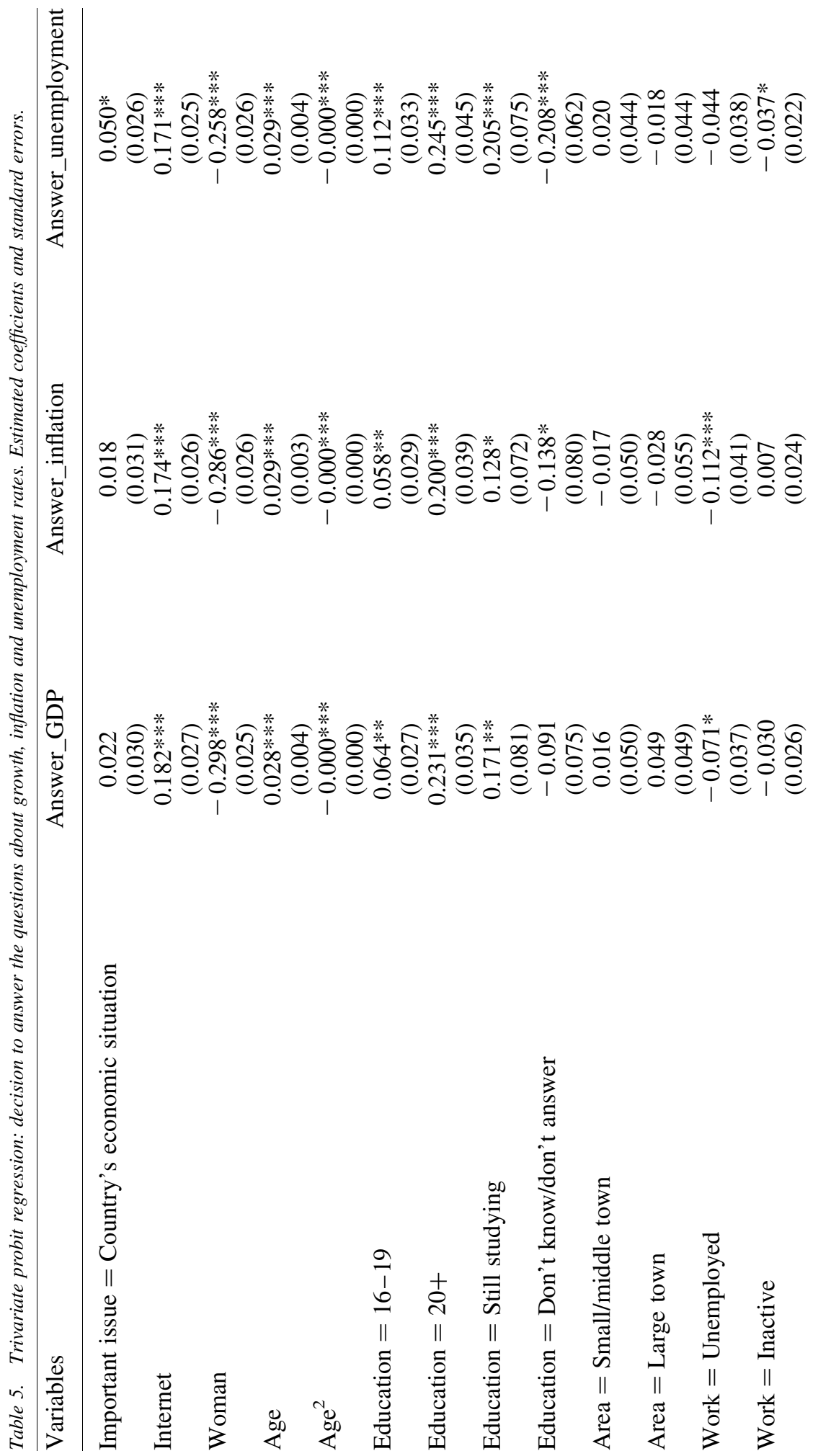




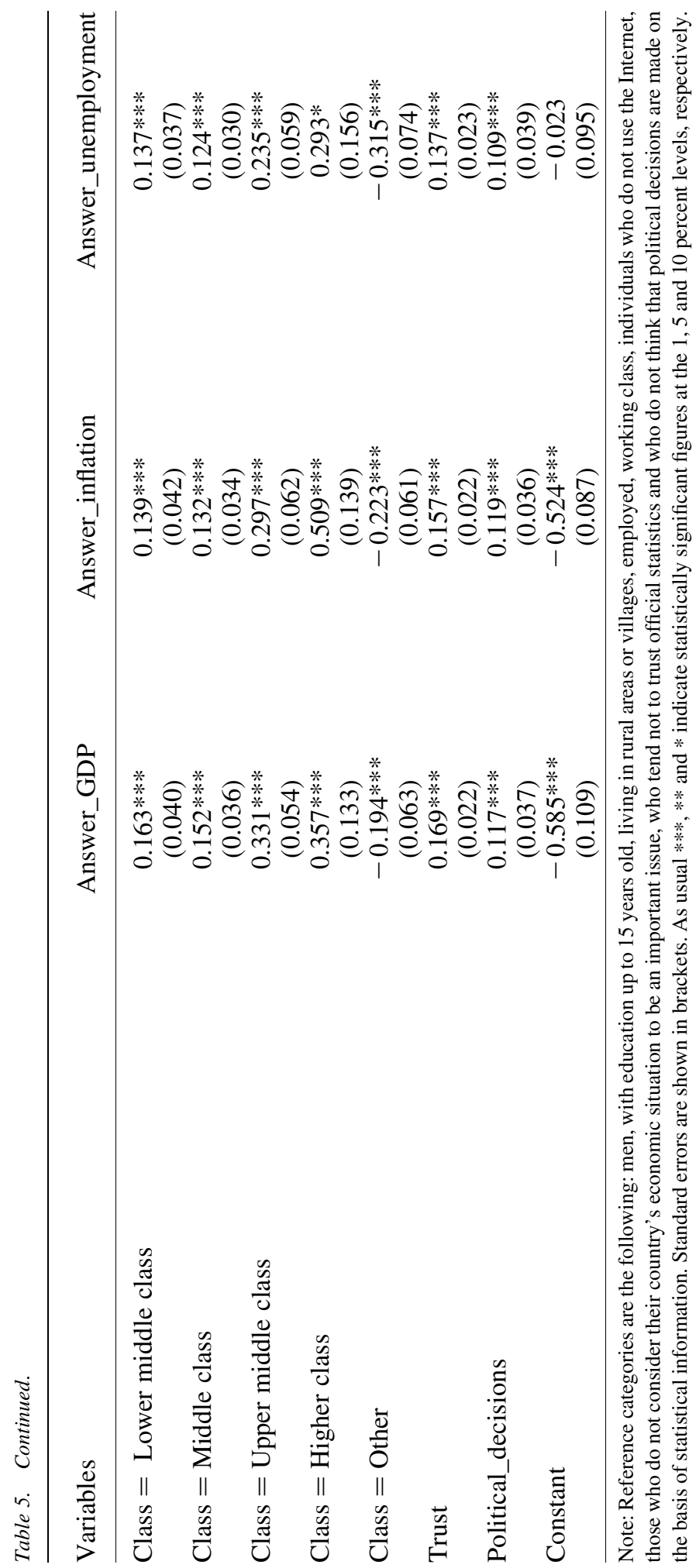




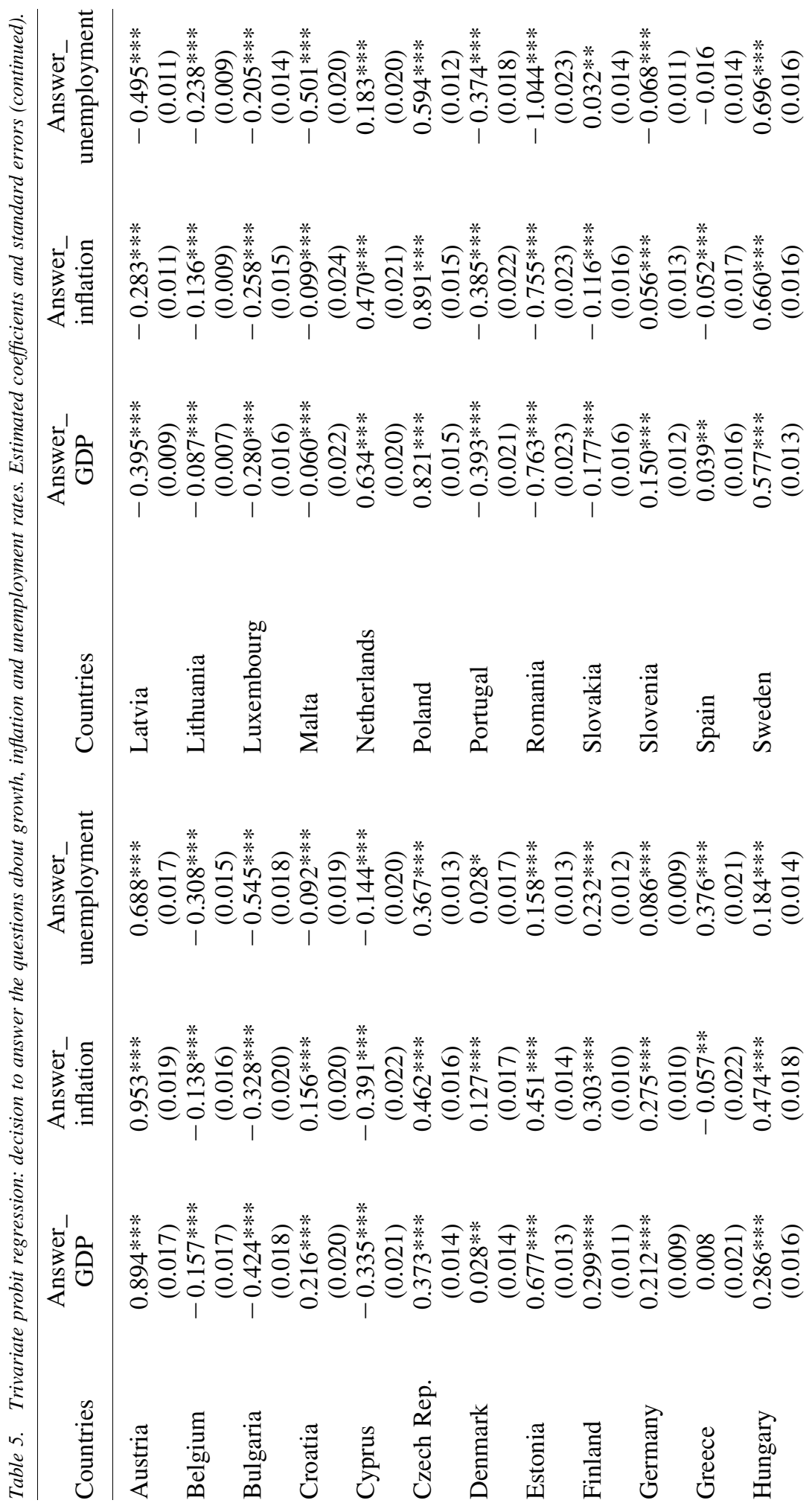




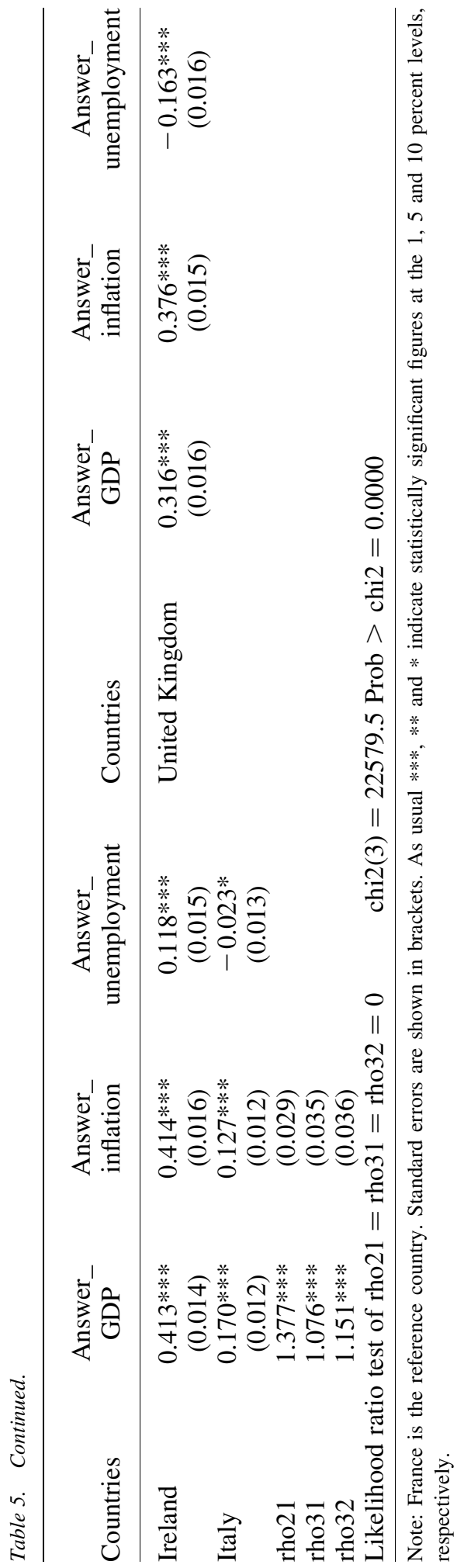




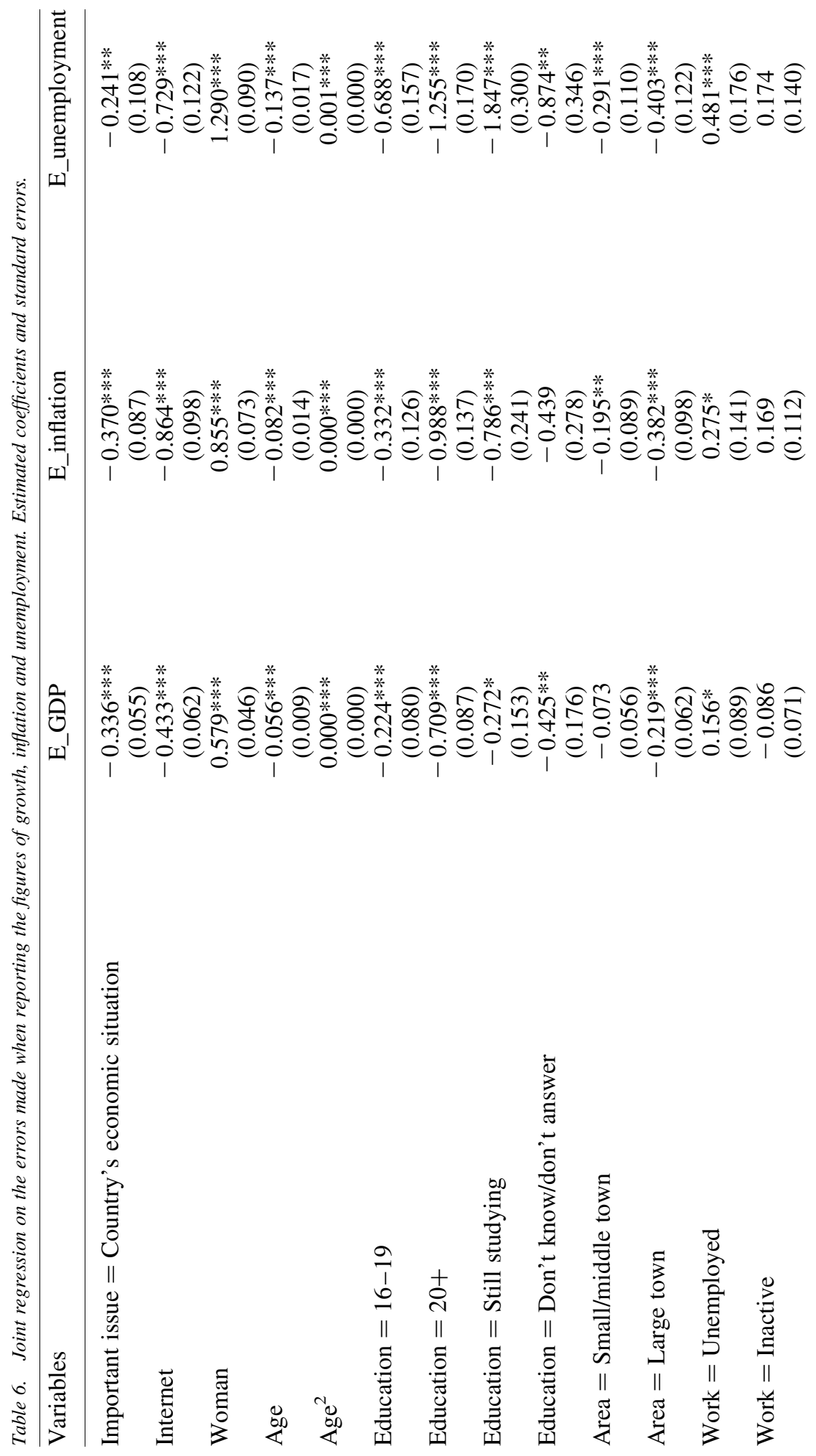




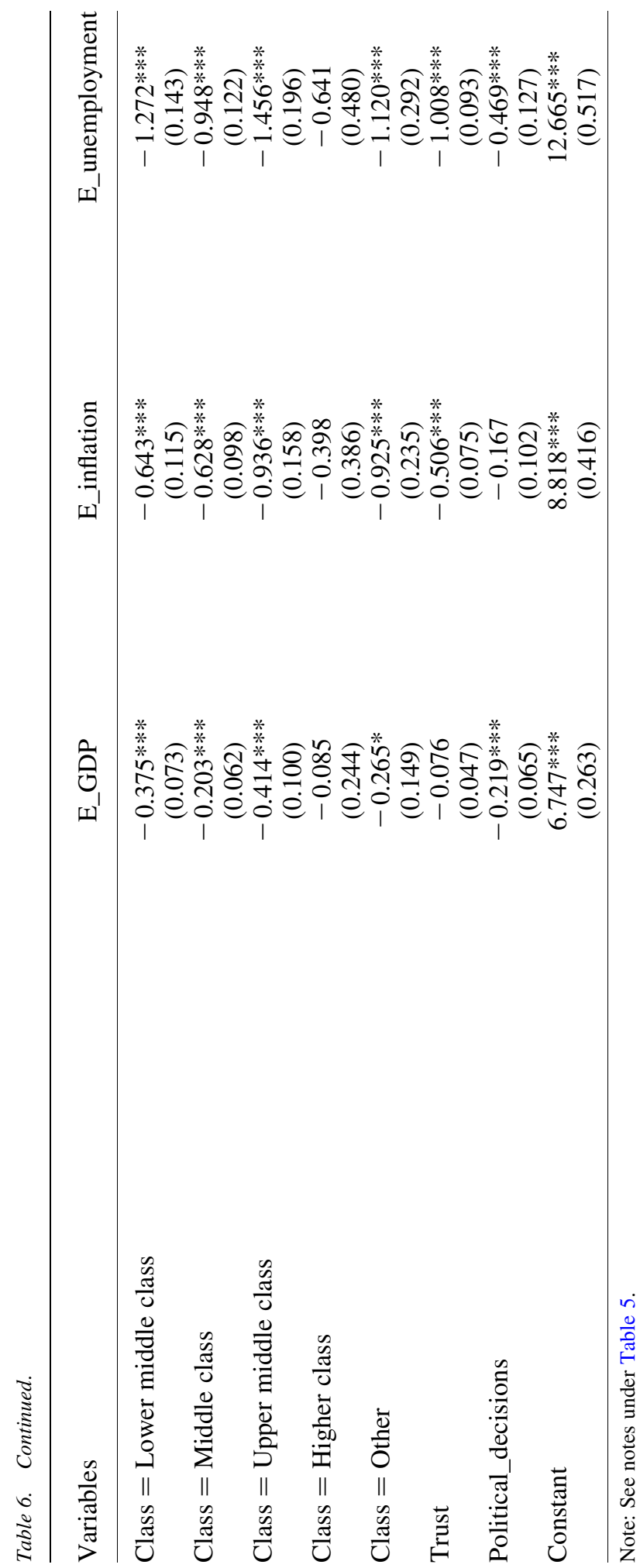




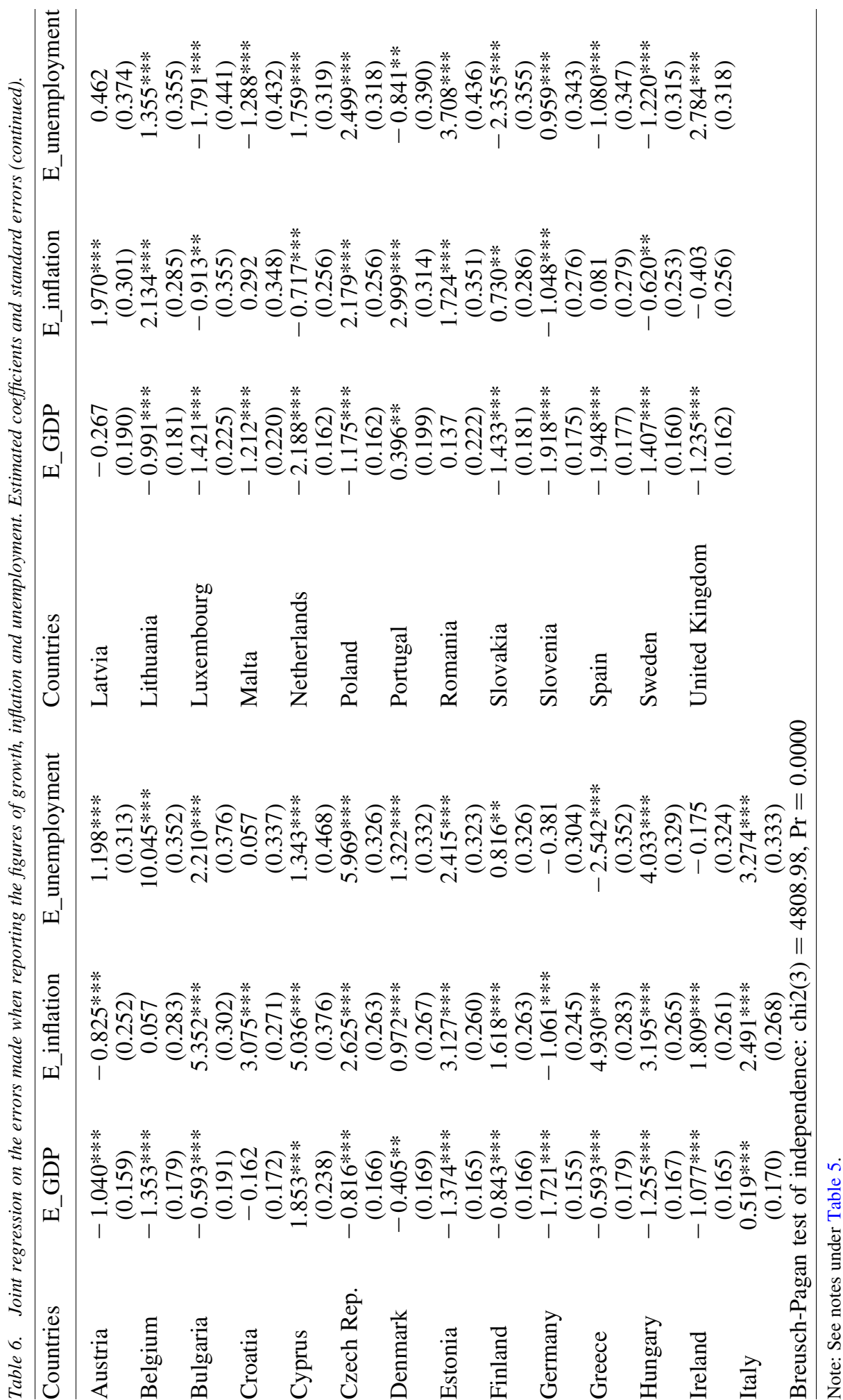


questions about the figures of GDP growth, inflation and unemployment. Results show that most of the explanatory variables are statistically significant and perform as expected. The only exceptions are those related to the perceived importance of the economic situation and the type of area. In particular, the fact that a national economic situation is considered to be important only has a significant effect (at the ten percent level) on the probability of answering the question on unemployment, but not for GDP or inflation; meanwhile, the type of area is not statistically significant in any of the three equations. In contrast, daily Internet use has a significant positive effect on the probability of answering any of the questions. The positive coefficients indicate that people using the Internet are more likely to answer these questions than those who do not use it. As regards individuals' personal characteristics, our estimates confirm the existence of wide variation among socioeconomic groups. In particular, we observe that groups that have been traditionally considered as socially disadvantaged are less likely to answer. We find, for instance, that unemployed individuals are less likely to answer than those in work. This likelihood increases with the level of education and social class. Note how the magnitudes of the coefficients of education and class increase as their levels rise. Hence, the higher the education and social class, the more likely they are to answer. While there is an indication that the age relationship is non-linear, the non-linear impact is not strong across the ages in the survey; older people are more likely to answer the questions. Moreover, country dummies are statistically significant, mostly at the one percent level. While the interpretation of all those estimates is quite complex, finding them significant indicates the existence of important cross-country differences with regard to the economic knowledge of their respective populations. As previously mentioned, these differences might be related to some extent to the effect of providing common guidelines for answers. The $p$-value of the likelihood ratio test leads to the rejection of the null hypothesis of the absence of correlation between the equations, which suggests the suitability of the proposed trivariate probit compared to the estimation of three independent equations.

Table 6 presents the estimates for the trivariate regressions of the errors made when reporting the rates of GDP growth, inflation and unemployment. Negative coefficients indicate smaller errors and subsequently better knowledge of economic indicators; correspondingly, positive coefficients suggest larger errors and thus poorer knowledge. In this case, all the considered determinants are statistically significant. The appropriateness of the joint estimation has been checked using the Breusch-Pagan test.

Results show that people who regard the economic situation as important and who use the Internet are less likely to make large errors than those who do not. Likewise, individuals who declare that they trust official statistics and believe that political decisions are based on them tend to make smaller errors. As previous research has noted, the value of official statistics is directly linked to people's trust and their perceived usefulness (Gore et al. 1991; Giovanni et al. 2008, 2015; Holt 2008; Papacostas 2008). The pattern of variation across socioeconomic groups is quite similar to the one observed when analyzing the decision to answer, and it broadly confirms the main findings of the literature. Hence, the largest errors and, consequently, the worst knowledge, are observed among young and socially disadvantaged groups (Walstad 1997; Walstad and Rebeck 2002; Blinder and Krueger 2004; Curtin 2008, 2009; Malgarini 2009; Giovannini et al. 2015). In particular, respondents with education up to 15 years old, who belong to the working class, who do 
not work or are out of the labor market and live in rural areas, tend to make the largest errors. Our estimates also show that women tend to make larger errors than men. This result confirms previous findings in the literature (Bryan and Venkatu 2001; Walstad and Rebeck 2002; Blinder and Krueger 2004; Curtin 2008, 2009; Giovannini et al. 2015). Such gender gaps might be related to different levels of economic/financial literacy (Bruine de Bruin et al. 2010; Burke and Manz 2014); in fact, women appear to be much more financially illiterate compared to men (Lusardi and Mitchell 2008; Fonseca et al. 2012). In the particular case of inflation, it has also been suggested that gender differences might be related to men and women's different shopping experiences (Jonung 1981; Jonung and Laidler 1988; Bryan and Venkatu 2001).

Country dummies are again statistically significant. In order to shed some light on these country effects, Figures 4-6 show countries ordered by the size of the errors for growth, inflation and unemployment, respectively. For GDP, the largest errors are found in Cyprus, followed by Italy and Portugal; for inflation, in Bulgaria, Cyprus and Greece; and for unemployment, in Hungary and Romania. Such country effects could be related to both demand and supply side factors. On the demand side, there might be differences between countries in terms of the importance that their populations place on official statistics and whether they trust them. In this sense, it could be conjectured that countries in which citizens trust official statistics and find them important, would have smaller errors. Since our database contains this information at the individual level, these two factors have already been considered in our models. As previously explained, results indicate that those individuals who trust official statistics and believe that they are the base for political decisions make smaller errors. Accordingly, countries in which the levels of trust in official statistics were high and where citizens believed that they were used for policy-making, would tend to have better knowledge of economic figures. Additionally, the observed country effect could be related to differences in a population's levels of economic/

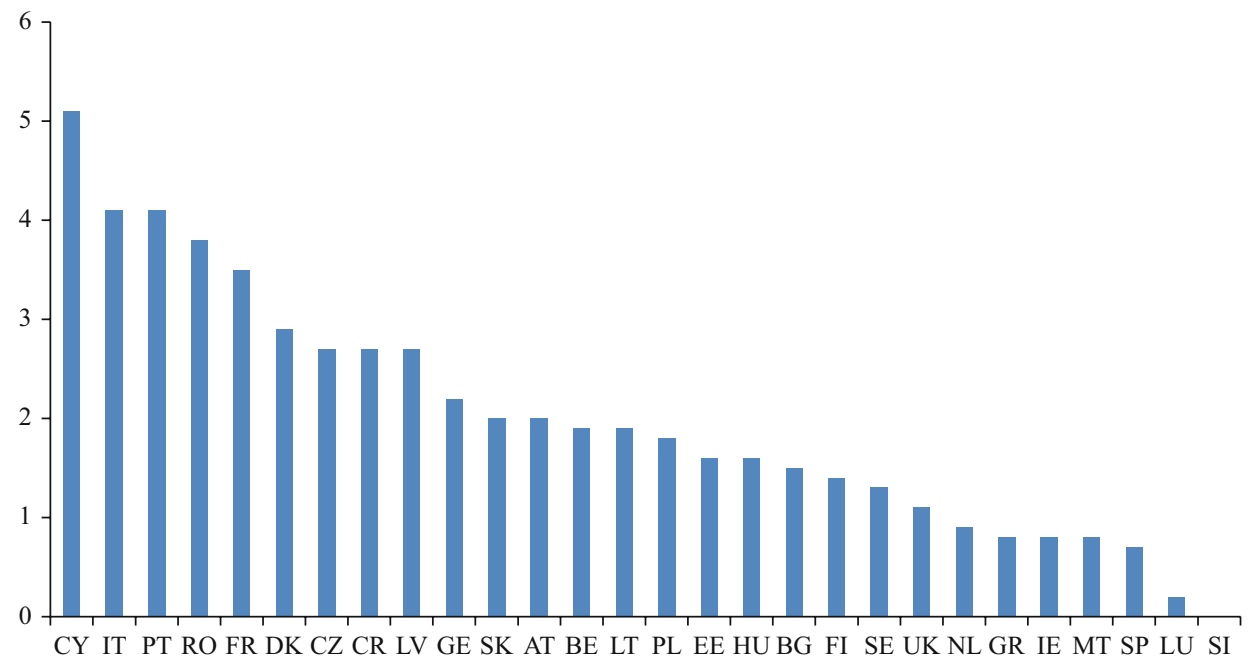

Fig. 4. Errors in growth reporting by country (in percent). Source: Own elaboration using data from the European Commission (2015a,c). Notes: Errors have been calculated as the difference between the average estimated rate and the official rate. For the meaning of the acronyms, see notes under Figure 1. 


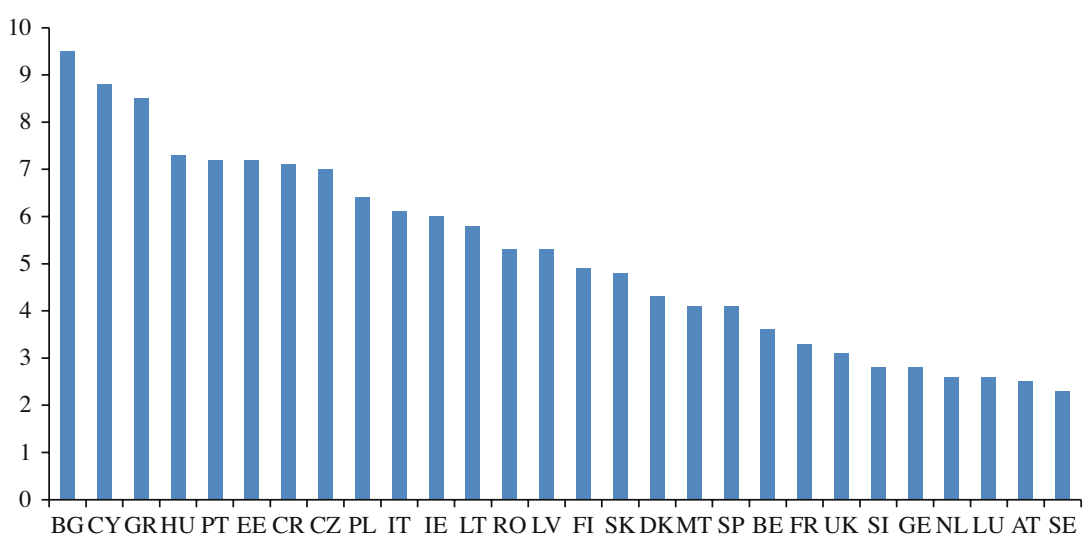

Fig. 5. Errors in inflation reporting by country (in percent). Source: Own elaboration using data from the European Commission $(2015 a, c)$. Notes: See notes under Figure 4.

financial literacy. When individuals are economically/financially literate, they are able to choose the relevant information and apply it efficiently in decision-making (Bruine de Bruin et al. 2010; Burke and Manz 2014). Hence, countries with highly economically/ financially literate populations would be expected to have lower errors. In the case of the European Union, some recent data indicate that there is great variation in levels of financial literacy across the Member States: from $22 \%$ of adults being financially literate in Romania to $71 \%$ in Sweden and Denmark (Klapper et al. 2015). The correlation coefficients between the errors and the levels of financial literacy are -0.43 for GDP, -0.55 for inflation and 0 for unemployment. The negative signs for GDP and inflation imply that countries with higher literacy tend to show lower errors. In fact, if we include

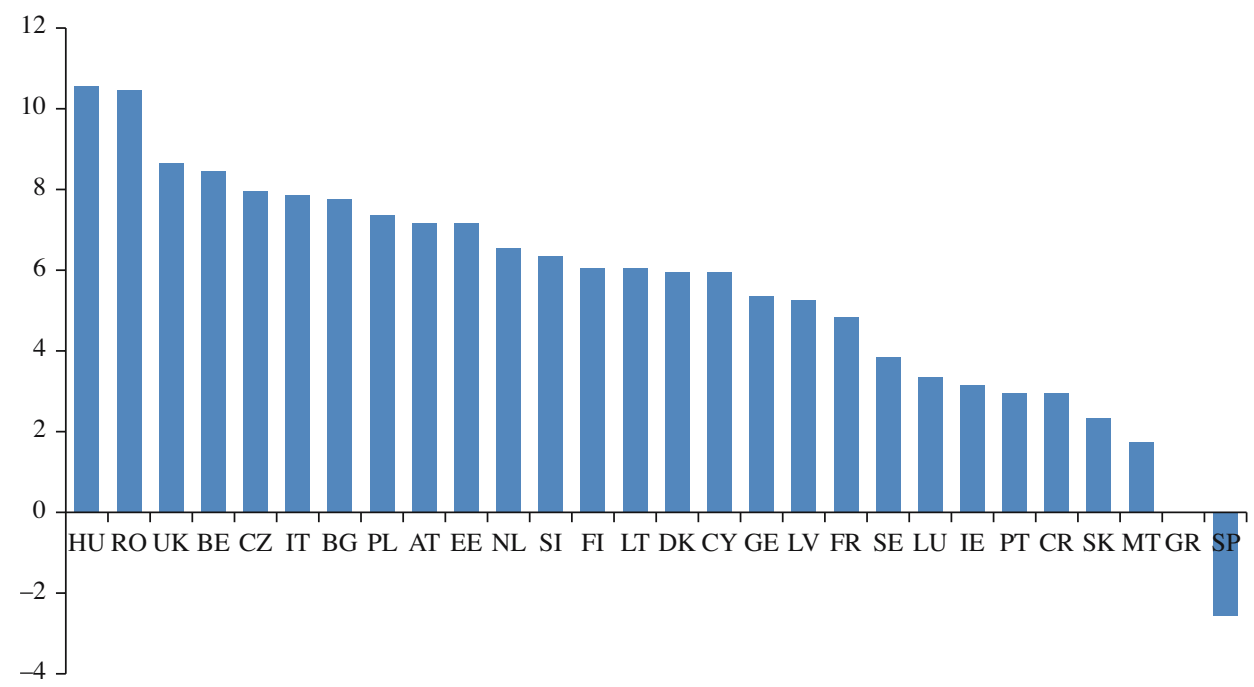

Fig. 6. Errors in unemployment reporting by country (in percent). Source: Own elaboration using data from the European Commission (2015a,c). Notes: See notes under Figure 4. Spain has a negative error due to the underestimation of the official rate of unemployment. 
financial literacy as an explanatory variable in the trivariate regression on the errors, we find that it is statistically significant at the 1 percent level in the case of GDP and inflation: the estimated coefficients (and standard errors) are: $-0.033(0.002),-0.080(0.002)$ and 0.001 (0.004) for the equations of GDP, inflation and unemployment, respectively. Such results might indicate that the more complexity involved in the concepts and figures of GDP and inflation as compared to those of unemployment.

On the supply side, countries might differ in how data are released and how the media reports these data. In this sense, we could expect that countries in which data were reported more widely and accurately would have lower errors. Curtin $(2008,2009)$ investigated the coverage of official statistics by the American media and found that there was some inadequate communication of the figures of inflation and growth: they were less frequently reported in the media than unemployment, and they were generally reported in qualitative terms rather than quantitative. Hence, the low level of knowledge of the population might be explained, at least to some extent, by inadequate coverage by the media.

As to data release policies, the Internet has become the main channel for wide dissemination of official figures. National statistical offices publish all new data releases on their websites, where they can be accessed by everyone. Furthermore, online social networks are increasingly used to announce data releases. In this sense, we have studied the presence of statistical agencies on two of the most popular social networks (i.e., Twitter and Facebook). Though data releases published on social networks do not reach the full population (but only those who use the social networks), it is worth studying them, given the increasing importance of social networks. Table 7 summarizes the presence of statistical offices on Twitter.

From January 2017, all European statistical agencies have a Twitter account except for Slovakia and Bulgaria. Luxembourg was first to open an account, in 2007, followed by Estonia, Ireland, the Netherlands, Slovenia, and Sweden in 2009. The last countries to join were Malta and Poland in January and November 2016, respectively. Some statistical offices have accounts in more than one language - usually their national language and English (e.g., Belgium, Germany, and Finland, among others). There is great variation in the use of this network among countries: the United Kingdom is by far the most active user, and also has the largest number of followers. Other countries that stand out are Spain, France, and the Netherlands. Though all institutions use this network to disseminate and announce their data releases, the type of messages published varies: for example, some of them mainly report economic news in qualitative rather than quantitative terms, some include tables with the tweets, and others just post the announcement of a new press release. With regard to Facebook, less than half of the offices have a profile on this social network. Unlike Twitter, which directly provides the figure of the total number of tweets, it is more difficult to know the total number of posts. Moreover, we note that interaction with users varies across agencies: some have implemented the option to send a message while others have not. In addition, the time they take to answer varies: from very responsive to messages to no information. In order to get some understanding on whether errors might be related to dissemination actions on online social networks, we have calculated the correlation coefficient between the errors and the average number of tweets per year, -0.03 , -0.36 , and -0.12 for GDP, inflation and unemployment, respectively. Interestingly enough, the figures are negative, which suggests that intense activity on 


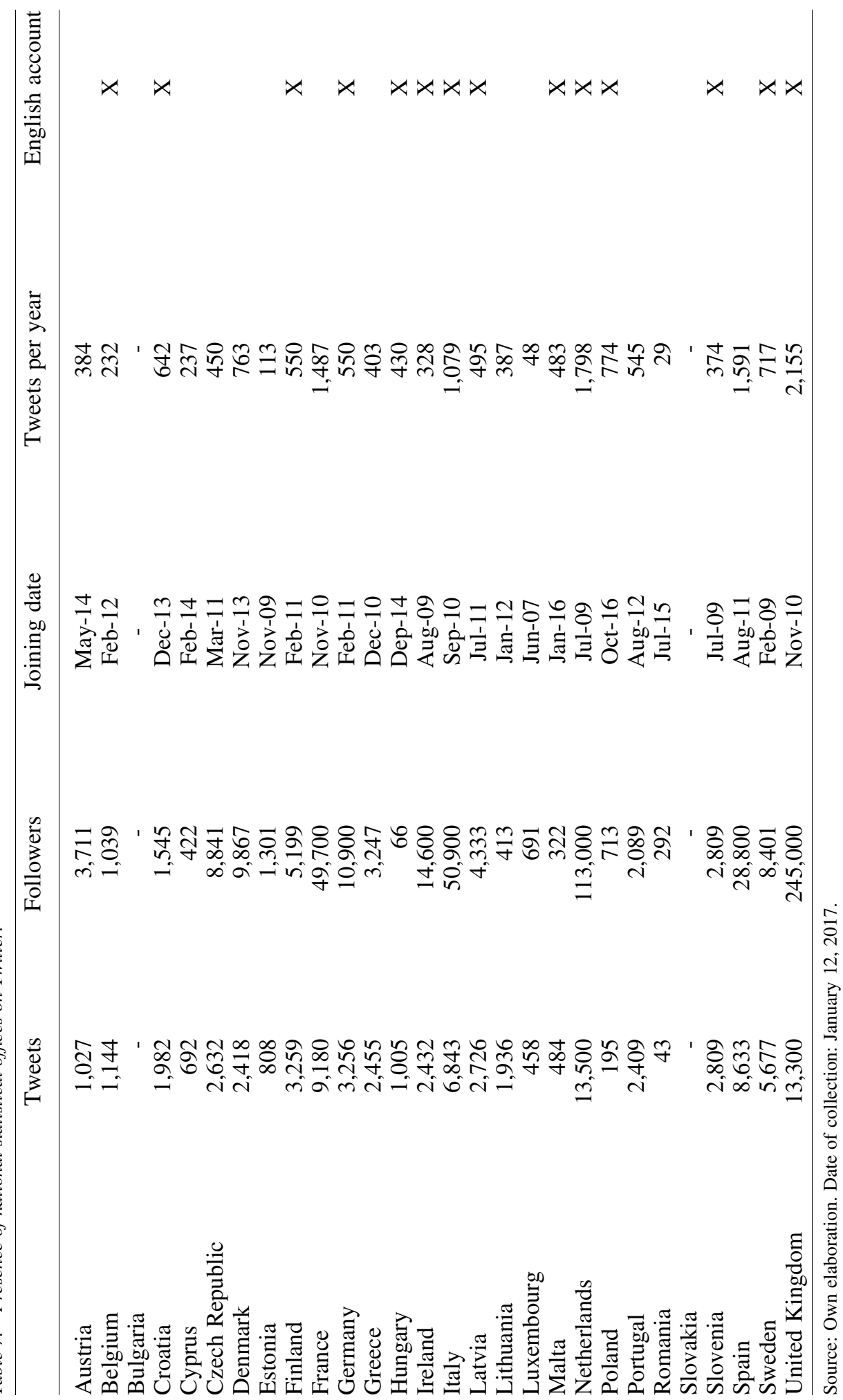


social networks (i.e., a high number of tweets) is associated with low errors. Though this finding is suggestive, it is important to take into account that it does not imply any causation. Moreover, we must note that the values of the coefficients are low.

Finally, Table 8 presents the estimates in the multinomial probit model on the evolution of the inflation rate. As previously indicated, the rate of people answering 'don't know' largely decreased when they were asked about the evolution. Nonetheless, the profile of individuals who answered correctly is very similar to the one observed in the other questions: people who use the Internet, men, with higher education levels or even still studying and in the upper middle or higher classes of society, who trust official statistics and think these are the basis for political decisions are those most likely to answer correctly. In contrast, neither the type of area nor the perceived importance of the economic situation has any significant influence.

\section{Summary of Findings and Concluding Remarks}

The aim of this article has been to assess Europeans' knowledge of some key economic statistics (i.e., GDP, inflation and unemployment) and to identify the determinants of such knowledge. Results show two main problems: people who don't know, and people who think they know when, in fact, they don't.

On the one hand, the rate of 'don't know' answers are quite important: almost one out of three Europeans indicate that they do not know the national rates of GDP or inflation, and about one out of five cannot report the unemployment rate or the evolution of prices between 2013 and 2014.

On the other hand, the level of knowledge of those who attempted to provide a figure is generally low: respondents' answers differed from the official figures up to five percentage points in the case of the growth rate, and up to ten percentage points for inflation and unemployment rates. We observe that there is a general tendency to overestimate official figures. In some countries, such overestimation suggests a complete misperception of the economic reality: people reporting positive rates of growth when the actual rates are negative (e.g., Cyprus and Italy); prices increasing when they are actually decreasing (e.g., Greece and Bulgaria).

Such gaps of knowledge appear to be shaped not only by individuals' socioeconomic characteristics, but also by their trust in official statistics and their perceived usefulness. Moreover, cross-country differences seem to be related to a population's level of financial literacy, and also possibly to data release policies.

In light of these findings, some recommendations can be suggested in order to improve knowledge of these statistics and to stimulate their demand and use. As Gabriel Tarde (1903) predicted, we have reached a point in time when very accurate statistical information is readily available to the public. However, people don't know this, or think they know when they actually don't; and they do not use statistics properly for decisionmaking. Even when official statistics are readily available, individuals tend to rely on less accurate sources of information (Cavallo et al. 2016). Hence, it seems crucial that producers of official statistics design campaigns to communicate the value of official statistics to the general public. Such campaigns should aim at making people understand the reasons why official statistics are important, that is, to make them aware of their 


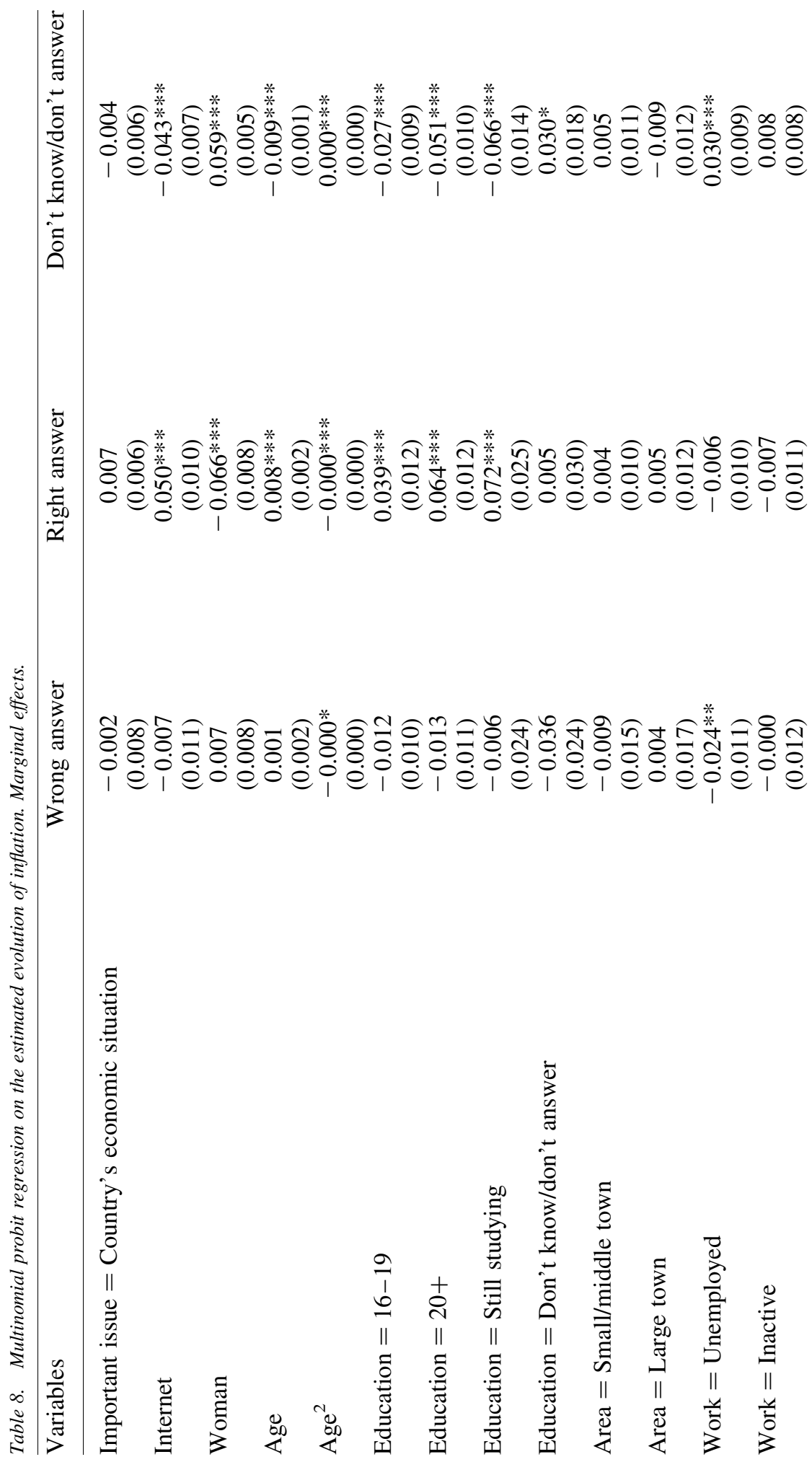




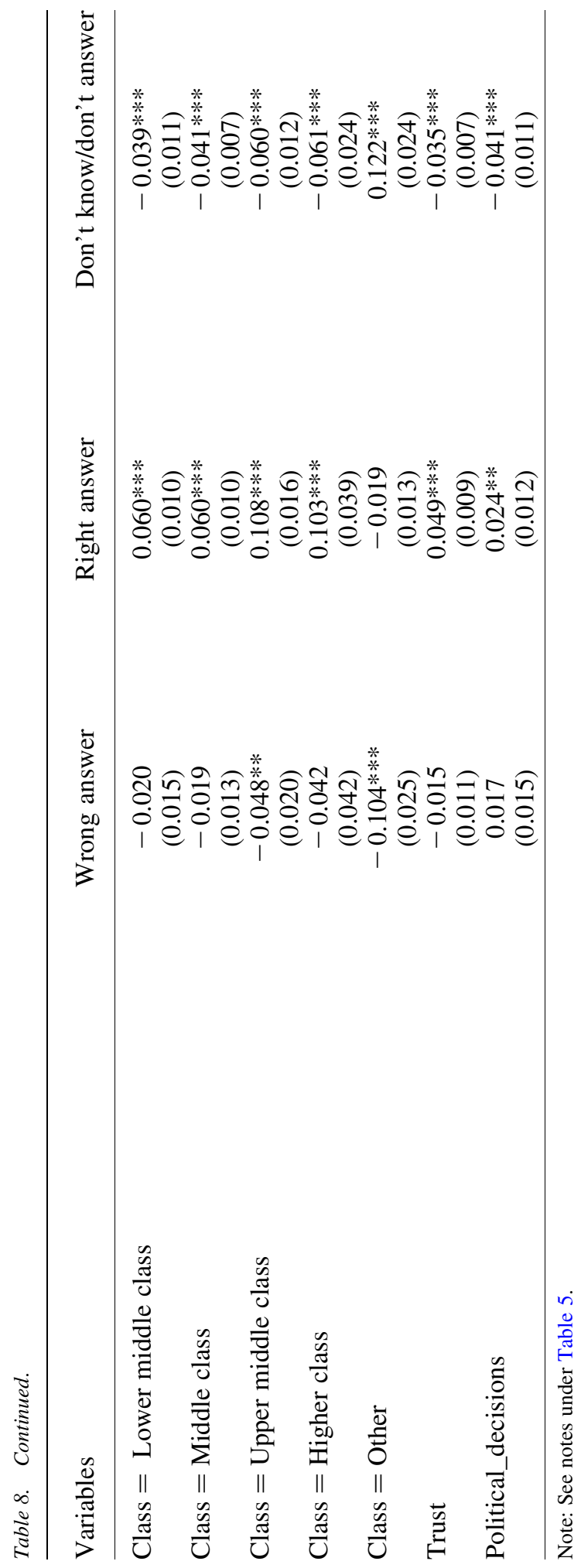




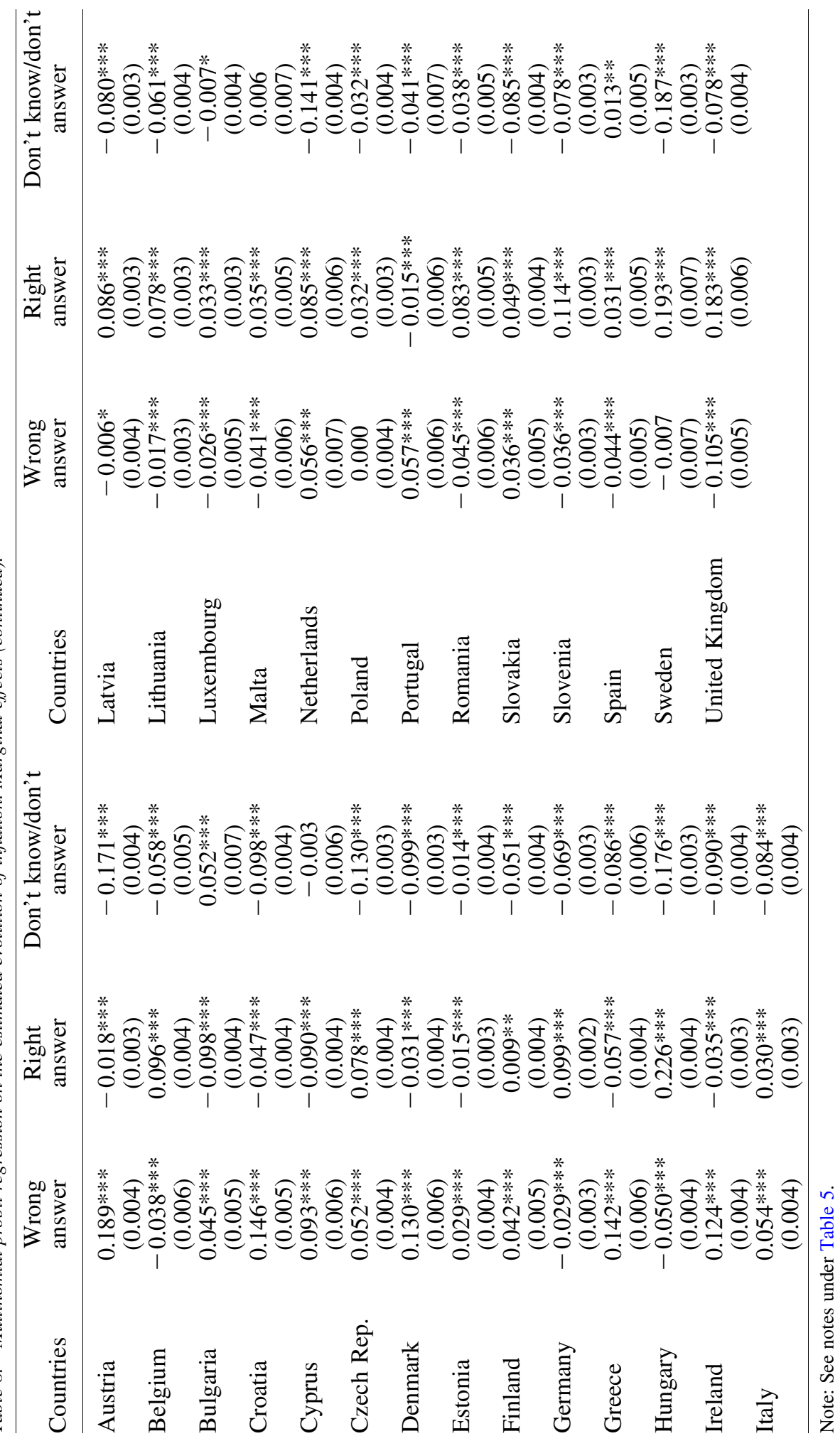


usefulness. They should highlight how this economic information is used in daily life and how the misunderstanding of economic figures could lead to poor decision-making. The misperception of inflation figures may have an impact on household consumption and decisions on savings (Duffy and Lunn 2009; Carrillo and Emran 2012); the misperception of unemployment rates may alter people's economic and political attitudes (Kunovich 2012) and labor outcomes (Cardoso et al. 2016). For instance, people, who overestimate unemployment figures may consider that they have little bargaining power and hence lower their reservation wages, that is, the lowest wage at which they are willing to work, which would thus result in a lower actual wage (Cardoso et al. 2016). Additionally, economic knowledge influences people's opinion on public issues (Blendon et al. 1997; Walstad 1997; Walstad and Rebeck 2002; Blinder and Krueger 2004). Becoming better informed is not only self-serving, but also provides an improved basis for decisionmaking. As Stigler $(1962,103)$ indicated in the case of the labor market: "The information a man possesses on the labor market is capital: it was produced at the cost of search, and it yields a higher wage rate than on average would be received in its absence”. While the cost of search has dramatically decreased thanks to new technologies, having the most accurate information is crucial for achieving the best possible outcomes. Special efforts should be devoted to communicating GDP and inflation figures since our findings suggest that that these two indicators are the least known by the general public. Communication campaigns should try to clearly explain how these economic figures are produced and the guarantees the production process offers in order to foster people's trust in them. Moreover, and given the low levels of knowledge, programs of statistical literacy for the adult population appears to be a must. While target population for this kind of program is usually students, our results suggest that they should also address the adult population. In particular, findings indicate that the demographic groups most in need of help are those who are least educated, in lower social classes, unemployed and women. Hence, the importance of designing target training actions for these groups in order to improve their understanding and knowledge of official statistics; and also to show them how they can use statistics for decision-making. Additionally, the role of online social networks as a channel for statistical news should be further explored. Our analysis reveals the existence of important differences in the use of these social networks by statistical offices. In fact, some agencies have not started using them. Given the increasing number of users, it is very likely that they will be a major tool for the wide diffusion of statistical news in the near future. 


\section{Appendix}

Table A1. Joint regression on the absolute errors (z-scores). Estimated coefficients and standard errors.

\begin{tabular}{|c|c|c|c|}
\hline Variables & z_GDP & z_inflation & z_unemployment \\
\hline $\begin{array}{l}\text { Important issue }=\text { Country's } \\
\text { economic situation }\end{array}$ & $\begin{array}{c}-0.108 * * * \\
(0.018)\end{array}$ & $\begin{array}{c}-0.071 * * * \\
(0.017)\end{array}$ & $\begin{array}{l}-0.037 * * \\
(0.016)\end{array}$ \\
\hline Internet & $\begin{aligned}- & 0.140 * * * \\
& (0.020)\end{aligned}$ & $\begin{array}{c}-0.166 * * * \\
(0.019)\end{array}$ & $\begin{array}{c}-0.111 * * * \\
(0.019)\end{array}$ \\
\hline Woman & $\begin{array}{c}0.187 * * * \\
(0.015)\end{array}$ & $\begin{array}{c}0.165 * * * \\
(0.014)\end{array}$ & $\begin{array}{c}0.196 * * * \\
(0.014)\end{array}$ \\
\hline Age & $\begin{array}{l}-0.018 * * * \\
(0.003)\end{array}$ & $\begin{array}{c}-0.016^{* * * *} \\
(0.003)\end{array}$ & $\begin{array}{c}-0.021 * * * \\
(0.003)\end{array}$ \\
\hline $\mathrm{Age}^{2}$ & $\begin{array}{l}0.000 * * * \\
(0.000)\end{array}$ & $\begin{array}{l}0.000 * * * \\
(0.000)\end{array}$ & $\begin{array}{c}0.000 * * * \\
(0.000)\end{array}$ \\
\hline Education $=16-19$ & $\begin{array}{c}-0.072 * * * \\
(0.026)\end{array}$ & $\begin{array}{c}-0.064 * * * \\
(0.024)\end{array}$ & $\begin{array}{c}-0.104 * * * \\
(0.024)\end{array}$ \\
\hline Education $=20+$ & $\begin{array}{l}-0.228 * * * \\
(0.028)\end{array}$ & $\begin{array}{l}-0.190 * * * \\
(0.026)\end{array}$ & $\begin{array}{c}-0.191 * * * \\
(0.026)\end{array}$ \\
\hline Education $=$ Still studying & $\begin{array}{c}-0.088^{*} \\
(0.049)\end{array}$ & $\begin{aligned}- & 0.151^{* * * *} \\
& (0.046)\end{aligned}$ & $\begin{array}{c}-0.280 * * * \\
(0.046)\end{array}$ \\
\hline Education = Don't know/don't answer & $\begin{array}{l}-0.137 * * \\
(0.057)\end{array}$ & $\begin{array}{l}-0.084 \\
(0.054)\end{array}$ & $\begin{array}{l}-0.133^{* *} \\
(0.052)\end{array}$ \\
\hline Area $=$ Small/middle town & $\begin{array}{l}-0.023 \\
(0.018)\end{array}$ & $\begin{array}{l}-0.038^{* *} \\
(0.017)\end{array}$ & $\begin{array}{c}-0.044 * * * \\
(0.017)\end{array}$ \\
\hline Area $=$ Large town & $\begin{array}{c}-0.071 * * * \\
(0.020)\end{array}$ & $\begin{array}{c}-0.074 * * * \\
(0.019)\end{array}$ & $\begin{array}{c}-0.061 * * * \\
(0.018)\end{array}$ \\
\hline Work $=$ Unemployed & $\begin{array}{l}0.050^{*} \\
(0.029)\end{array}$ & $\begin{array}{l}0.053^{*} \\
(0.027)\end{array}$ & $\begin{array}{c}0.073 * * * \\
(0.027)\end{array}$ \\
\hline Work $=$ Inactive & $\begin{array}{l}-0.028 \\
(0.023)\end{array}$ & $\begin{array}{c}0.032 \\
(0.022)\end{array}$ & $\begin{array}{c}0.026 \\
(0.021)\end{array}$ \\
\hline Class $=$ Lower middle class & $\begin{array}{c}-0.121 * * * \\
(0.024)\end{array}$ & $\begin{array}{c}-0.124 * * * \\
(0.022)\end{array}$ & $\begin{array}{c}-0.193 * * * \\
(0.022)\end{array}$ \\
\hline Class $=$ Middle class & $\begin{array}{c}-0.066 * * * \\
(0.020)\end{array}$ & $\begin{array}{c}-0.121 * * * \\
(0.019)\end{array}$ & $\begin{array}{c}-0.144 * * * \\
(0.019)\end{array}$ \\
\hline Class $=$ Upper middle class & $\begin{array}{c}-0.134 * * * \\
(0.032)\end{array}$ & $\begin{array}{c}-0.180 * * * \\
(0.030)\end{array}$ & $\begin{array}{c}-0.221 * * * \\
(0.030)\end{array}$ \\
\hline Class $=$ Higher class & $\begin{array}{l}-0.027 \\
(0.079)\end{array}$ & $\begin{array}{l}-0.077 \\
(0.074)\end{array}$ & $\begin{array}{l}-0.097 \\
(0.073)\end{array}$ \\
\hline Class $=$ Other & $\begin{array}{l}-0.085^{*} \\
(0.048)\end{array}$ & $\begin{array}{c}-0.178^{* * *} \\
(0.045)\end{array}$ & $\begin{array}{c}-0.170 * * * \\
(0.044)\end{array}$ \\
\hline Trust & $\begin{array}{l}-0.025 \\
(0.015)\end{array}$ & $\begin{array}{c}-0.097 * * * \\
(0.014)\end{array}$ & $\begin{array}{c}-0.153 * * * \\
(0.014)\end{array}$ \\
\hline Political_decisions & $\begin{array}{c}-0.071 * * * \\
(0.021)\end{array}$ & $\begin{array}{l}-0.032 \\
(0.020)\end{array}$ & $\begin{array}{c}-0.071 * * * \\
(0.019)\end{array}$ \\
\hline Constant & $\begin{array}{c}1.167 * * * \\
(0.085)\end{array}$ & $\begin{array}{c}0.671 * * * \\
(0.080)\end{array}$ & $\begin{array}{c}0.840 * * * \\
(0.079)\end{array}$ \\
\hline
\end{tabular}

Note: See notes under Table 5. Z_GDP, z_inflation and z_unemployment stand for the z-scores of the absolute errors made when reporting the rates of growth, inflation and unemployment, respectively. These $\mathrm{z}$-scores have been calculated by standardizing the absolute errors with respect to the mean and standard deviation of their distribution. 


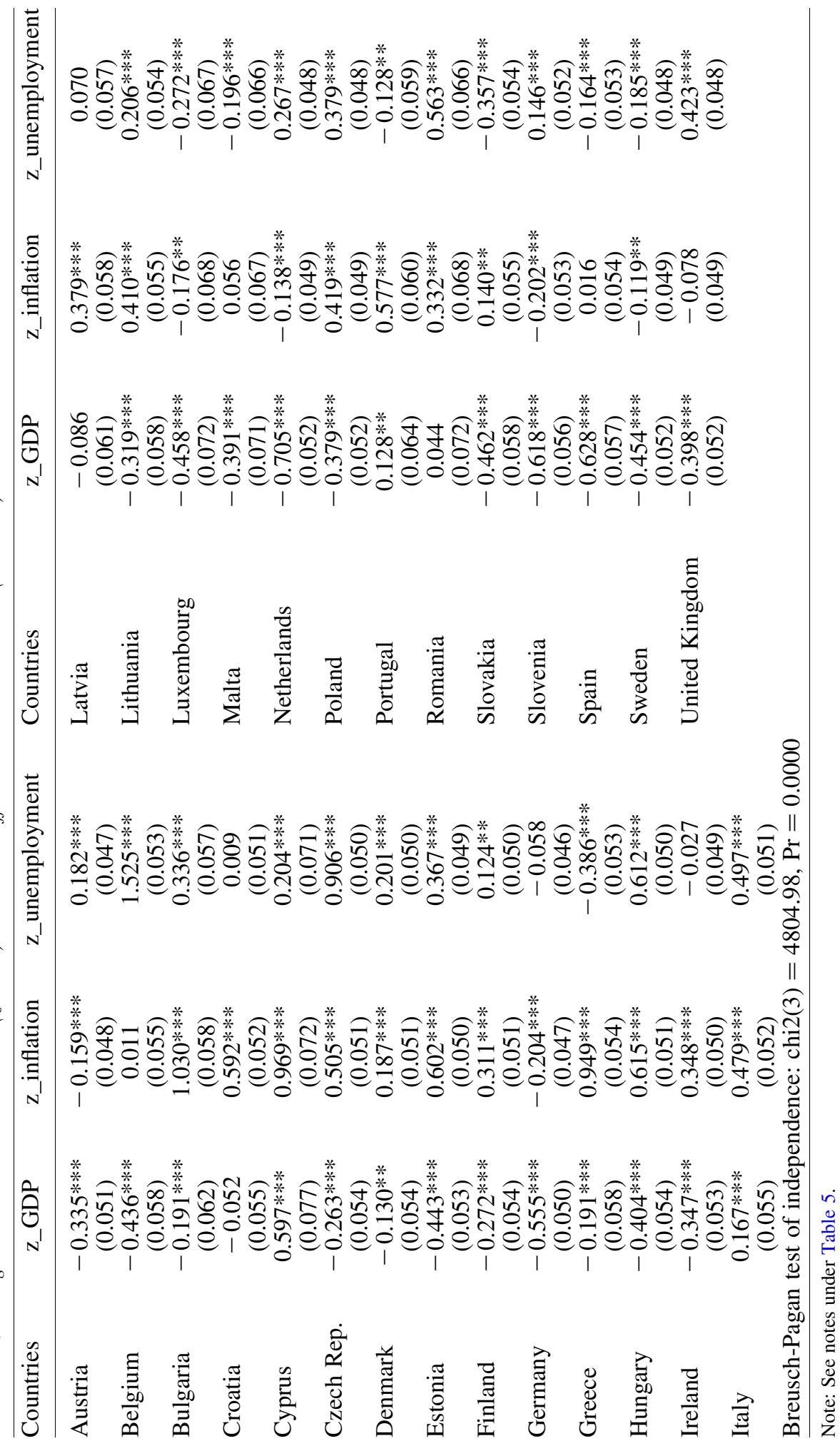




\section{References}

Akerlof, G.A. 1970. "The Market for Lemons: Quality Uncertainty and the Market Mechanism." Quarterly Journal of Economics 84: 488-500. Available at: http://www. jstor.org/stable/1879431.

Akerlof, G.A., W. Dickens, and G. Perry. 2000. "Near-Rational Wage and Price Setting and the Optimal Rates of Inflation and Unemployment." Brookings Papers on Economic Activity 1: 1-58. Doi: http://dx.doi.org/10.1353/eca.2000.0001.

Bacchetta, P. and E. van Wincoop. 2005. "Rational Inattention: A Solution to the Forward Discount Puzzle.” NBER Working Paper 11633. Doi: http://dx.doi.org/10.3386/ w11633.

Blendon, R.J., J.M. Benson, M. Brodie, R. Morin, D.E. Altman, D. Gitterman, M. Brossard, and M. James. 1997. "Bridging the Gap between the Public's and Economists' Views of the Economy.” Journal of Economic Perspectives 11: 105-118. Doi: http://dx.doi.org/10.1257/jep. 11.3.105.

Blinder, A.S. and A.B. Krueger. 2004. "What does the Public Know about Economic Policy, and How Does It Know It?" Brookings Papers on Economic Activity 1: 327-387. Doi: http://dx.doi.org/10.3386/w10787.

Bruine de Bruin, W., W. Vanderklaauw, J.S. Downs, B. Fischhoff, G. Topa, and O. Armantier. 2010. "Expectations of Inflation: The Role of Demographic Variables, Expectation Formation, and Financial Literacy." Journal of Consumer Affairs 44: 381-402. Doi: http://dx.doi.org/10.1111/j.1745-6606.2010.01174.x.

Bryan, M. and G. Venkatu. 2001. "The Curiously Different Inflation Perspectives of Men and Women." Federal Reserve Bank of Cleveland Economic Commentary Series November.

Burke, M.A. and M. Manz. 2014. "Economic Literacy and Inflation Expectations: Evidence from a Laboratory Experiment." Journal of Money, Credit and Banking 46: 1421-1456. Doi: http://dx.doi.org/10.1111/jmcb.12144.

Cappellari, L. and S.P. Jenkins. 2003. "Multivariate Probit Regression Using Simulated Maximum Likelihood?" Stata Journal 3: 278-294. Stable URL: http://www. stata-journal.com/sjpdf.html?articlenum $=$ st0045.

Cardoso, A.R., A. Loviglio, and L. Piemontese. 2016. "Misperceptions of Unemployment and Individual Labor Market Outcomes." IZA Journal of Labor Policy 5: 1-22. Doi: http://dx.doi.org/10.1186/s40173-016-0069-6.

Carrillo, P.E. and M.S. Emran. 2012. "Public Information and Inflation Expectations: Microeconometric Evidence from a Natural Experiment." Review of Economics and Statistics 94: 860-877. Doi: http://dx.doi.org/10.1162/REST_a_00213.

Carroll, C. 2003. "Macroeconomic Expectations of Households and Professional Forecasters.” Quarterly Journal of Economics 118: 269-298. Doi: http://dx.doi.org/10. 1162/00335530360535207.

Cavallo, A., G. Cruces, and R. Perez-Truglia. 2016. Inflation Expectations, Learning and Supermarket Prices. Evidence from Survey Experiments. Available at: http://www.mit. edu/ afc/papers/Cavallo-Inflation-Expectations.pdf (accessed April 2017). 
Curtin, R. 2008. "What U.S. Consumers Know About Economic Conditions.” In Statistics, Knowledge and Policy 2007: Measuring and Fostering the Progress of Societies, edited by OECD, 153-176. Paris: OECD.

Curtin, R. 2009. "What U.S. Consumers Know About the Economy: The Impact of Economic Crisis on Knowledge?" In Proceedings of the 3rd OECD World Forum on Statistics, Knowledge and Policy: Charting Progress, Building Visions, Improving Life: OECD, 27-30 October, 2009. Busan, Korea. Available at: http://www.oecd.org/site/ progresskorea/44129683.pdf (accessed April 2017).

Duffy, D. and P.D. Lunn. 2009. “The Misperception of Inflation by Irish Consumers.” The Economic and Social Review 40: 139-163. URL: http://hdl.handle.net/2262/58798.

European Commission. 2007. Special Eurobarometer 67.2. Europeans' Knowledge of Economic Indicators. Luxembourg: European Commission.

European Commission. 2015a. Eurobarometer 83.3. Brussels: TNS Opinion (producer). Cologne: Gesis Data Archive. Doi: http://dx.doi.org/10.4232/1.12356.

European Commission. 2015b. Europeans and Economic Statistics. Luxembourg: European Commission.

European Commission. 2015c. European Economic Forecast. Spring 2015. Luxembourg: European Commission.

European Commission. 2015d. Media Use in the European Union. Standard Eurobarometer 82. Luxembourg: European Commission.

Eurostat. 2016a. About Eurostat. Overview. Available at: http://ec.europa.eu/eurostat/ about/overview (accessed April 2016).

Eurostat. 2016b. Glossary: Gross Domestic Product. Available at: http://ec.europa.eu/ eurostat/statistics-explained/index.php/Glossary:Gross_domestic_product_(GDP) (accessed December 2016).

Eurostat. 2016c. Glossary: Inflation. Available at: http://ec.europa.eu/eurostat/ statistics-explained/index.php/Glossary:Inflation (accessed December 2016).

Eurostat. 2016d. Glossary: Unemployment. Available at: http://ec.europa.eu/eurostat/ statistics-explained/index.php/Glossary:Unemployment (accessed December 2016).

Eurostat. 2016e. Information Society Statistics. Internet Activities. Available at: http://ec. europa.eu/eurostat/web/information-society/data/database (accessed April 2016).

Fonseca, R., K.J. Mullen, G. Zamarro, and J. Zissimopoulos. 2012. "What Explains the Gender Gap in Financial Literacy? The Role of Household Decision Making." Journal of Consumer Affairs 46: 90-106. Doi: http://dx.doi.org/10.1111/j.1745-6606.2011.01221.x.

Gal, I. 2002. "Adults' Statistical Literacy: Meanings, Components, Responsibilities." International Statistical Review 70: 1-51. Doi: http://dx.doi.org/10.1111/j.1751-5823. 2002.tb00336.x.

Giovannini, E., J. Oliveira Martins, and M. Gamba. 2008. "Statistics, Knowledge and Governance." In Proceedings of the Workshop Committing Science to Global Development: Tropical Research Institute, September 29-30, 2008. Lisbon, Portugal. Available at: http://docentes.fe.unl.pt/ lpereira/papers.html (accessed April 2017).

Giovannini, E., M. Malgarini, and R. Sonego. 2015. "What Do Italian Consumers Know About Economic Data? An Analysis Based on the ISTAT Consumers Survey." Rivista Di Statistica Ufficiale 3: 25-47. Available at: http://www.istat.it/it/files/2016/06/Whatdo-Italian-consumers-know-about-Economic-Data.pdf (accessed December 2016). 
Gore, S.M., T. Holt, and I.P. Fellegi. 1991. "Maintaining Public Confidence in Official Statistics." Journal of the Royal Statistical Society. Series A 154: 1-6. Stable URL: http://www.jstor.org/stable/2982687.

Greene, W.H. 2011. Econometric Analysis (7 ${ }^{\text {th }}$ edition). New York: Pearson.

Holt, T. 2008. "Official Statistics, Public Policy and Public Trust." Journal of the Royal Statistical Society Series A 171: 323-346. Doi: http://dx.doi.org/10.1111/j.1467-985X. 2007.00523.x.

Jonung, L. 1981. "Perceived and Expected Rates of Inflation in Sweden." American Economic Review 71: 961-968. Stable URL: http://www.jstor.org/stable/1803477.

Jonung, L. and D.E. Laidler. 1988. "Are Perceptions of Inflation Rational? Some Evidence for Sweden." American Economic Review 78: 1080-1087. Stable URL: http://www. jstor.org/stable/1807167.

Kahneman, D. and A. Tversky. 1979. "Prospect Theory: An Analysis of Decision under Risk." Econometrica 47: 263-291. Doi: http://dx.doi.org/10.2307/1914185.

Klapper, L., A. Lusardi, and P. van Oudheusden. 2015. Financial Literacy around the World. Available at: http://gflec.org/wp-content/uploads/2015/11/Finlit_paper_16_F2_ singles.pdf (accessed January 2017).

Kunovich, R.M. 2012. "Perceived Unemployment. The Sources and Consequences of Misperception." International Journal of Sociology 42: 100-123. Doi: http://dx.doi. org/10.2753/IJS0020-7659420405.

Lucas, R.E. Jr. 1972. "Expectations and the Neutrality of Money." Journal of Economic Theory 4: 103-124. Doi: http://dx.doi.org/10.1016/0022-0531(7290142-1).

Lusardi, A. and O. Mitchell. 2008. "Planning and Financial Literacy: How Do Women Fare?” American Economic Review 98: 413-417. Doi: http://dx.doi.org/10.1257/aer. 98.2.413.

Malgarini, M. 2009. "Quantitative Inflation Perceptions and Expectations of Italian Consumers." Giornale degli Economisti e Annali di Economia 68: 53-80. Stable URL: http://www.jstor.org/stable/41954986.

Mankiw, N.G. and R. Reis. 2002. "Sticky Information versus Sticky Prices: A Proposal to Replace the New Keynesian Phillips Curve." NBER Working Paper 8290. Doi: http://dx.doi.org/10.3386/w8290.

Natcen. 2015. Public Confidence in Official Statistics. Available at: http://www.natcen.ac. uk/media/833802/public-confidence-in-official-statistics_-final.pdf (accessed April 2016).

Northern Ireland Statistics and Research Agency. 2015. Public Awareness of and Confidence in Official Statistics in Northern Ireland 2014. Available at: http://www. nisra.gov.uk/aboutus/index.html (accessed April 2016).

OECD. 2005. Statistics, Knowledge and Policy. Key Indicators to Inform Decision Making. Paris: OECD.

Ottaviani, M.G. 2002. "Statistics, from a Tool for State and Society to a Tool for All Citizens." International Statistical Review 70: 30-32. Doi: http://dx.doi.org/10.1111/j. 1751-5823.2002.tb00338.x.

Papacostas, S. 2008. "Special Eurobarometer: European Knowledge on Economical Indicators." In Statistics, Knowledge and Policy 2007: Measuring and Fostering the Progress of Societies, edited by OECD, 177-196. Paris: OECD. 
Reis, R. 2006. "Inattentive Consumers.” Journal of Monetary Economics 53: 1976-1800. Doi: http://dx.doi.org/10.1016/j.jmoneco.2006.03.001.

Rose, N. 1991. "Governing by Numbers: Figuring out Democracy." Accounting, Organizations and Society 16: 673-692. Doi: http://dx.doi.org/10.1016/ 0361-3682(91)90019-B.

Sims, C.A. 2003. "Implications of Rational Inattention.” Journal of Monetary Economics 50: 665-690. Doi: http://dx.doi.org/10.1016/S0304-3932(03)00029-1.

Souleles, N.S. 2001. "Consumer Sentiment: Its Rationality and Usefulness in Forecasting Expenditures-Evidence from the Michigan Micro Data.” NBER Working Paper 8410. Doi: http://dx.doi.org/10.3386/w8410.

Stigler, G.J. 1962. "Information in the Labor Market." Journal of Political Economy 70: 94-105. Stable URL: https://www.jstor.org/stable/1829106.

Tarde, G. 1903. The Laws of Imitation. New York: Henry Holt and Company.

Townsend, R. 1983. "Forecasting the Forecasts of Others." Journal of Political Economy 91: 546-588. Doi: http://dx.doi.org/10.1086/261166.

United Nations General Assembly. 2010. Resolution 64/267. World Statistics Day. Available at: http://www.un.org/en/ga/search/view_doc.asp?symbol=A/RES/64/267 (accessed April 2016).

Walstad, W.B. 1997. "The Effect of Economic Knowledge on Public Opinion of Economic Issues.” Journal of Economic Education 28: 195-205. Doi: http://dx.doi.org/ $10.2307 / 1183198$.

Walstad, W.B. and K. Rebeck. 2002. "Assessing the Economic Knowledge and Economic Opinions of Adults." The Quarterly Review of Economics and Finance 42: 921-935. Doi: http://dx.doi.org/10.1016/S1062-9769(01)00120-X.

Wild, C. 2005. "Education is Everybody's Responsibility." International Statistical Review 73: 213-214. Doi: http://dx.doi.org/10.1111/j.1751-5823.2005.tb00274.x.

Received August 2016

Revised July 2017

Accepted July 2017 